\title{
Stand type affects fluxes of volatile organic compounds from the forest floor in hemiboreal and boreal climates
}

\author{
Mari Mäki $@$ D. Krasnov • H. Hellén • S. M. Noe • \\ J. Bäck
}

Received: 10 January 2019/Accepted: 3 May 2019/Published online: 24 May 2019

(C) The Author(s) 2019

\begin{abstract}
Aims The forest floor is a significant contributor to the stand-scale fluxes of biogenic volatile organic compounds. In this study, the effect of tree species (Scots pine vs. Norway spruce) on forest floor fluxes of volatile organic compounds (VOC) was compared in boreal and hemiboreal climates.

Methods Monoterpenoid and sesquiterpene flux rates were determined during 2017-2018 using dynamic (steady-state flow-through) chambers placed on permanent soil collars on boreal and hemiboreal forest floors, where the canopy was formed by Scots pine (Pinus sylvestris), Norway spruce (Picea abies) or dominated
\end{abstract}

Responsible Editor: Zucong Cai.

Electronic supplementary material The online version of this article (https://doi.org/10.1007/s11104-019-04129-3) contains supplementary material, which is available to authorized users.

M. Mäki $(\bowtie) \cdot J$. Bäck

Institute for Atmospheric and Earth System Research / Forest

Sciences, Helsinki, Finland

e-mail: mari.maki@helsinki.fi

M. Mäki · J. Bäck

Faculty of Agriculture and Forestry, University of Helsinki, Helsinki, Finland

D. Krasnov · S. M. Noe

Institute of Agricultural and Environmental Sciences, Estonian University of Life Sciences, Tartu, Estonia

H. Hellén

Finnish Meteorological Institute, Helsinki, Finland by Scots pine with small coverage of Norway spruce and birches (Betula pendula and Betula pubescens). Results The total monoterpenoid fluxes were higher from the Scots pine forest floor (boreal $23 \mu \mathrm{g} \mathrm{m}^{-2} \mathrm{~h}^{-1}$ ) and from the mixed forest floor (hemiboreal $32 \mu \mathrm{g} \mathrm{m}^{-2} \mathrm{~h}^{-1}$ ) compared to the Norway spruce forest floor in both boreal (12 $\left.\mu \mathrm{g} \mathrm{m}^{-2} \mathrm{~h}^{-1}\right)$ and hemiboreal $\left(9 \mu \mathrm{g} \mathrm{m}^{-2} \mathrm{~h}^{-1}\right)$ climates. Due to higher litterfall production, the forest floor seems to be a greater source of monoterpenoids and sesquiterpenes in the hemiboreal mixed stand dominated by Scots pine compared to the boreal Scots pine stand, although the difference was not statistically significant. Forest floor VOC fluxes followed a similar seasonal dynamic in different forest stands, with the highest flux rates in spring and summer. Significant VOC sources in the boreal forest floor were synthesis and release from vegetation and living roots together with litter decomposition of fungi and other microbes, where VOCs are released from needle storage pools. Ground vegetation in the hemiboreal forest is scanty under the dense tree canopy, meaning soil processes, such as litter decomposition, microbial metabolism and root release, were likely the dominating VOC sources. VOC fluxes from the hemiboreal forest floor were reduced by increases in soil moisture.

Conclusions This study indicates that if the warming climate changes tree species' abundance and stand biomass, by increasing tree growth and coverage of broadleaf species, it may affect VOC fluxes from the forest floor and impact the total VOC emissions from northern soils. 
Keywords Volatile organic compound · Forest floor -

Stand type $\cdot$ Chamber measurements $\cdot$ Flux

\section{Introduction}

Boreal and hemiboreal forests form a diverse biome, where species composition, vegetation structure, and soil properties vary depending on site history and prevailing climate. Boreal and hemiboreal forests affect atmospheric chemistry by releasing biogenic volatile organic compounds (BVOCs) (Bourtsoukidis et al. 2014a; Hakola et al. 2017; Rantala et al. 2014), such as oxygenated volatile organic compounds, sesquiterpenes and monoterpenes. Monoterpene emissions contribute $11 \%$ of global BVOC emissions (Sindelarova et al. 2014) and affect the global secondary organic aerosol yield due to oxidation reactions with $\mathrm{OH}, \mathrm{NOx}$ and $\mathrm{O}_{3}$ (Jokinen et al. 2015). If boreal forests transition to hemiboreal forests in a warming climate, higher BVOC fluxes may affect atmospheric chemistry. Also, if the boreal, hemiboreal and temperate vegetation zones move northwards in the warming climate (Lathiere et al. 2005; Hickler et al. 2012; Noe et al. 2016), it could also increase the total BVOC emissions from the biosphere. Forest floor processes, releasing VOCs, contribute significantly to forest stand fluxes (Aaltonen et al. 2013; Mäki et al. 2019). To determine the effect of climate on forest floor VOC fluxes in the Northern Hemisphere, we compared VOC fluxes from the forest floor between hemiboreal and boreal climates. This knowledge is required to predict how the total VOC emissions from northern forest floors may change in the warming climate.

Hemiboreal stands release more BVOCs than boreal stands (Bourtsoukidis et al. 2014a; Noe et al. 2011, 2012). Growing season length and temperatures are higher in hemiboreal ecosystems compared to boreal ecosystems, which may have implications to stand biomass and VOC biosynthesis and release of plants. Hemiboreal ecosystems are typically formed by mixed stands including both coniferous and broadleaf species (Bourtsoukidis et al. 2014a), which affects the VOC blend released by the forest stand and may increase ecosystem adaptability for the warming climate. Global warming may change tree species composition, which impacts VOC emissions released by forest canopies (Kellomäki et al. 2001). If tree cover changes in the Northern Hemisphere, there will also be an impact on ground vegetation cover and soil properties, which could alter forest floor VOC exchange. If warming increases stand biomass, VOCs from decomposing litter - a significant VOC source - could increase (Hayward et al. 2001; Mäki et al. 2017). Litter addition increases nutrient levels in soil (Rinnan et al. 2008), which may affect soil processes and further increase VOC fluxes from the boreal forest floor, as nitrogen availability typically restricts plant growth in the boreal forest (Näsholm et al. 1998). The effect of tree species and stand biomass on forest floor VOC fluxes was determined in this study.

Forest floor processes, releasing VOCs, might shift in response to the warmer climate. According to long-term remote sensing data, warming-induced changes in vegetation productivity and growing season length are already visible in the Northern Hemisphere (Park et al. 2016). Ground vegetation is affected when temperatures increase and nutrient levels change due to warming (Hedwall et al. 2015). Vegetation BVOC emissions from the subarctic heath were found to increase by warming induced vegetation change together with litter addition (Valolahti et al. 2015). Long-term warming in the forest-tundra may change vegetation cover, with declining lichen cover and increasing evergreen ericoid dwarf shrub cover (Vuorinen et al. 2017). Some studies have estimated that abundance or biomass of deciduous shrubs may increase in the warming climate (Tape et al. 2006; Rinnan et al. 2008), which may change VOC fluxes from the forest floors. Greater vegetation cover, caused by warming, may also increase fine root biomass and soil carbon content (Rinnan et al. 2008), which may accelerate microbial decomposition and VOC synthesis due to a higher amount of labile carbon i.e. easily available for microbes in the soil. Warming may have both direct and indirect effects on litter decomposition rates. Warming may directly increase microbial activity and indirectly affect microbial decomposition rates by changing vegetation cover, which regulates litter quality and quantity (Hobbie 1996; Cornelissen et al. 2007). Vegetation changes in the warming climate may influence microbial VOC synthesis on a global scale (Gray et al. 2010).

VOC sources likely differ between the boreal and hemiboreal forest floors. Forest floors are formed by varying microclimate, vegetation cover, and soil 
properties (texture, availability of water, oxygen and nutrients and amount of soil organic matter) and quality and quantity of fresh litter containing VOC storages varies between forest stands. Composition of metabolised VOCs likely varies between different soil types and climate conditions, because microbial enzyme activities and community structure are affected by soil moisture (Brockett et al. 2012; Veres et al. 2014). VOC release from ground vegetation and soil processes is also affected by soil moisture (Aaltonen et al. 2013; Asensio et al. 2007a; Bourtsoukidis et al. 2018; Svendsen et al. 2016). Microbial VOC synthesis occurs in both anaerobic and aerobic conditions (Seewald et al. 2010). Soil moisture reduces gas diffusion in soil (Zhong et al. 2014), although VOC bursts from litter have also been observed after rain (Greenberg et al. 2012). Soil may also be a VOC sink due to microbial driven degradation of VOCs (Cleveland and Yavitt 1998; Albers et al. 2018). Increasing soil moisture may stimulate microbial VOC uptake in soil and increase VOC dissolution into soil water, wet deposition of VOCs on soil surface and VOC leaching towards the bedrock (Cousins et al. 1999; Asensio et al. 2007a). Forest floor VOC exchange is also affected by VOC adsorption on soil particles (Cousins et al. 1999). The effect of soil moisture on forest floor VOC fluxes was compared between hemiboreal stands with higher soil water content and boreal stands with lower water content.

Activity of VOC sources may also vary depending on temperature. Forest floor VOC fluxes are typically correlated with temperature (Aaltonen et al. 2013; Mäki et al. 2017), as temperature regulates plant VOC biosynthesis, volatility of compounds, and VOC release from litter storage pools due to microbial decomposition (Guenther et al. 1993; Kesselmeier and Staudt 1999; Kainulainen and Holopainen 2002; Greenberg et al. 2012). For this reason, VOC flux rates may be higher from the hemiboreal forest floor compared to the boreal forest floor.

The aim of this study was to determine the effect of tree species and climate zone on forest floor VOC fluxes. We hypothesised: (1) Tree species affect the quality and quantity of decomposing litter, and therefore also VOC flux rates from the forest floor. (2) VOC flux rates are higher from the hemiboreal forest floor compared to the boreal forest floor due to higher litter production rate and higher temperatures that accelerate litter decomposition and VOC synthesis of microbes.

\section{Material and methods}

Research sites

We selected four measurement sites, two in hemiboreal forests and two in boreal. The first measurement site is an almost 60-year-old boreal Scots pine forest (Pinus sylvestris) located at the SMEAR II (Station for Measuring Ecosystem-Atmosphere Relations) station in Southern Finland on Haplic podzol soil $\left(61^{\circ} 51^{\prime} \mathrm{N}\right.$, $24^{\circ} 17^{\prime} \mathrm{E}, 180 \mathrm{~m}$ above sea level). The canopy is formed by Pinus sylvestris (75\%), Picea abies (15\%), and broadleaf trees (10\%) such as Betula pendula and Sorbus aucuparia. The second site is a boreal Norway spruce forest (Picea abies) located immediately adjacent $(100 \mathrm{~m})$ to the boreal Scots pine stand, also on Haplic podzol soil. The canopy basal area is formed by Picea abies. The third site is a hemiboreal mixed stand at the SMEAR Estonia station $\left(58^{\circ} 25^{\prime} \mathrm{N}, 27^{\circ} 46^{\prime} \mathrm{E}, 36 \mathrm{~m}\right.$ above sea level) (Noe et al. 2016). The canopy is formed by Scots pine (Pinus sylvestris) with small coverage of Norway spruce (Picea abies) and birches (Betula pendula and Betula pubescens). The fourth site is a hemiboreal Norway spruce (Picea abies) stand, located close $(200 \mathrm{~m})$ to the pine stand. The stand age for both Estonian stands is over 100 years (Noe et al. 2016). The soil is covered by a thick raw O-horizon with a mean thickness of $24 \mathrm{~cm}$ and hydraulic conductivity in soil is low due to high clay content (Noe et al. 2011). The hemiboreal forest floor is covered by mounds and pits with varying soil moisture, while the forest floor in the boreal stands is relatively flat. Measurement sites are described in more detail in Tables 1 and 2. Ground vegetation cover of the different stands is shown in the Table 2. The stand biomass is higher in the hemiboreal stands compared to the boreal stands due to the prevailing climate, soil properties (availability of nutrients) and forest management practices. Due to a dense tree canopy that limits light availability, ground vegetation cover was sparser in the hemiboreal stands compared to the boreal stands (Fig. 1).

VOC flux measurements from the forest floor and supporting data

Six permanent, stainless steel soil collars (height $7 \mathrm{~cm}$, diameter $21.7 \mathrm{~cm}$ ) were installed randomly at each measurement site: at site one in spring 2012, site two in spring 2017, and at sites three and four in spring 2016. 
Table 1 Features of measurement sites at the SMEAR II and SMEAR Estonia stations, including: tree cover, climate zone based on the Köppen-Geiger climate classification, annual mean temperature $\left({ }^{\circ} \mathrm{C}\right)$, the total annual precipitation $(\mathrm{mm})$, number of soil collars, soil type, and timing of the 2017 and 2018

\begin{tabular}{|c|c|c|c|c|c|c|c|c|c|}
\hline \multirow[t]{2}{*}{ Station } & \multirow[t]{2}{*}{ Site } & \multirow[t]{2}{*}{ Tree cover } & \multirow{2}{*}{$\begin{array}{l}\text { Climate } \\
\text { zone }\end{array}$} & \multirow{2}{*}{$\begin{array}{l}\text { Mean } \\
\text { temperature } \\
(\mathrm{oC})\end{array}$} & \multirow{2}{*}{$\begin{array}{l}\text { Total } \\
\text { precipitation } \\
(\mathrm{mm})\end{array}$} & \multirow{2}{*}{$\begin{array}{l}\text { Number } \\
\text { of soil } \\
\text { collars }\end{array}$} & \multirow[t]{2}{*}{ Soil type } & \multicolumn{2}{|c|}{ Measurements } \\
\hline & & & & & & & & 2017 & 2018 \\
\hline $\begin{array}{l}\text { SMEAR II } \\
\text { Finland }\end{array}$ & 1 & Scots pine stand & Cold & $3^{a}$ & $697^{\mathrm{a}}$ & 6 & Haplic Podzol & May-Oct & April-August \\
\hline $\begin{array}{l}\text { SMEAR II } \\
\text { Finland }\end{array}$ & 2 & $\begin{array}{l}\text { Norway spruce } \\
\text { stand }\end{array}$ & Cold & $3^{a}$ & $697^{\mathrm{a}}$ & 6 & Haplic Podzol & May-Oct & April-August \\
\hline $\begin{array}{l}\text { SMEAR } \\
\text { Estonia }\end{array}$ & 3 & $\begin{array}{l}\text { Mixed stand } \\
\text { dominated by } \\
\text { Scots pine }\end{array}$ & Cold & $4-6^{b}$ & $500-700^{b}$ & 6 & Haplic Gleysol & May-Oct & May-August \\
\hline $\begin{array}{l}\text { SMEAR } \\
\text { Estonia }\end{array}$ & 4 & $\begin{array}{l}\text { Norway spruce } \\
\text { stand }\end{array}$ & Cold & $4-6^{b}$ & $500-700 \mathrm{~b}$ & 6 & Haplic Gleysol & May-Oct & May-August \\
\hline
\end{tabular}

${ }^{\mathrm{a}}$ Ilvesniemi et al. 2010 and ${ }^{\mathrm{b}}$ Noe et al. 2012

From each collar, we measured isoprenoid flux rates using two glass steady state flow-through chambers (SMEAR II chamber: height $25 \mathrm{~cm}$ and chamber volume 61 and SMEAR Estonia chamber: height $30 \mathrm{~cm}$ and chamber volume 9.51 ). The used flow-through chamber technique has been tested earlier for carbon dioxide (Pumpanen et al. 2004). The headspace is equilibrated by flushing the system continuously (flow rate
1-1.5 $1 \mathrm{~min}^{-1}$ ) with filtered (active carbon trap and $\mathrm{MnO} 2$-coated copper net) ambient air to avoid chamber temperature increase during measurements. Isoprenoids were sampled by collecting incoming and outgoing air for 40-50 min through Tenax TA-Carboback-B adsorbent tubes using $0.1-0.21 \mathrm{~min}^{-1}$ flow rate. This measurement technique has been used earlier in VOC flux measurements from the forest floor (Hellén et al. 2006;

Table 2 Plant cover of the soil collars and soil properties in O-, A- and B-horizons for all the studied stands

\begin{tabular}{|c|c|c|c|c|}
\hline \multirow[b]{2}{*}{ Stand } & \multicolumn{2}{|l|}{ SMEAR II } & \multicolumn{2}{|c|}{ SMEAR Estonia } \\
\hline & Pine stand & Spruce stand & Mixed stand & Spruce stand \\
\hline Total plant coverage & IV & IV & II & II \\
\hline Coverage of Vaccinium vitis-idaea & $\mathrm{I}$ & II & & \\
\hline Coverage of Vaccinium myrtillus & II & II & I & \\
\hline Coverage of mosses & III & III & II & II \\
\hline Coverage of other plant species & $\mathrm{I}$ & & & \\
\hline $\mathrm{pH}$ in the O-horizon & 3.3 & & 2.9 & 2.9 \\
\hline $\mathrm{pH}$ in the A-horizon & 3.4 & & 2.9 & 3.2 \\
\hline $\mathrm{pH}$ in the B-horizon & 4.3 & & 3.3 & 3.9 \\
\hline $\mathrm{C} \%$ mass in the O-horizon & 37 & & 31 & 35 \\
\hline $\mathrm{C} \%$ mass in the A-horizon & 4 & & 18 & 4 \\
\hline $\mathrm{C} \%$ mass in the $\mathrm{B}$-horizon & 3 & & 3 & 1 \\
\hline $\mathrm{N} \%$ mass in the O-horizon & 1.3 & & 1.1 & 1.2 \\
\hline $\mathrm{N} \%$ mass in the A-horizon & 0.1 & & 0.6 & 0.2 \\
\hline $\mathrm{N} \%$ mass in the B-horizon & 0.1 & & 0.1 & 0.03 \\
\hline
\end{tabular}

Soil properties are means of five sampling points at the SMEAR II station and of three sampling points at the SMEAR Estonia station. Plant cover was determined based on visual assessment in July-August and divided into four categories, where the mean plant cover was 1-15\% (I), $16-45 \%$ (II), 46-70\% (III) and 71-100\% (IV) of the area of soil collars 

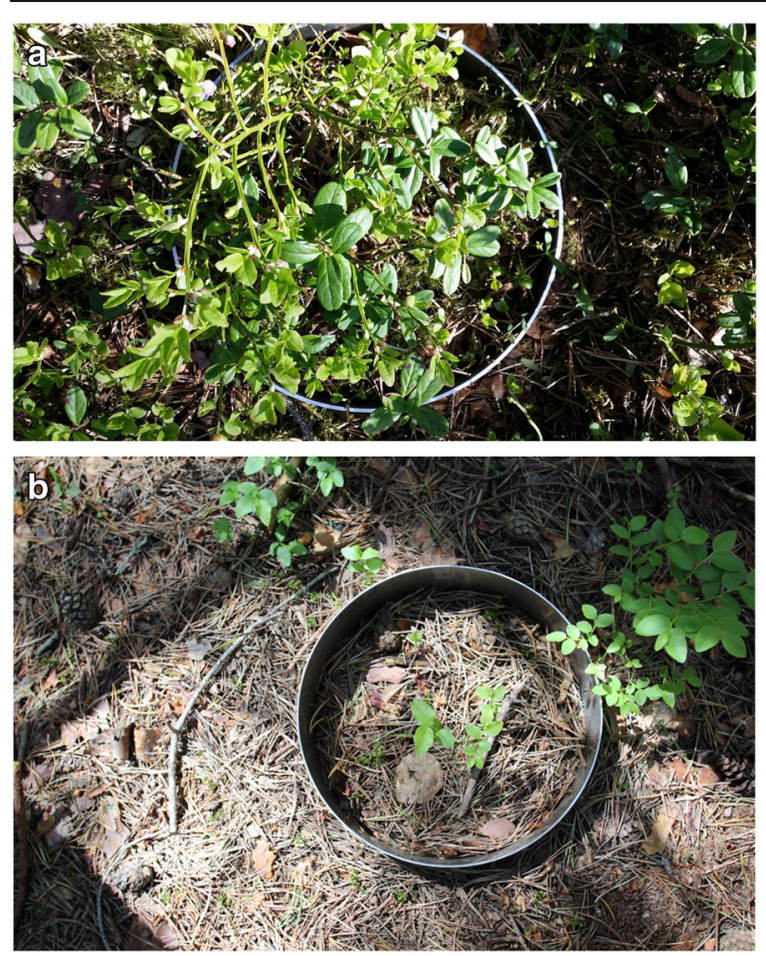

Fig. 1 Ground vegetation in the boreal Scots pine stand a at the SMEAR II station and in the hemiboreal Scots pine stand $\mathbf{b}$ at the SMEAR Estonia station

Aaltonen et al. 2011; Mäki et al. 2017). Isoprenoid flux rates from the forest floor were measured once a month from May to October in 2017 and from April to August in 2018. Isoprenoid fluxes were not measured at the SMEAR Estonia station in July 2017 and in April and June in 2018.

The chamber temperature was measured from the chamber headspace or from outlet sampling air using a thermometer. At the SMEAR II station, soil temperature was monitored using thermistors (Philips KTY81-110, Philips Semiconductors, Eindhoven, The Netherlands) and soil water content using the TDR method (TDR 100, Campbell Scientific, Inc., Logan, USA) from the O-, A-, B- and C-horizon $(n=5)$ in 2017-2018 (supporting data from the SMEAR II station is available from https://avaa.tdata.fi/web/smart). At the SMEAR Estonia station, soil water content and temperature were measured next to each soil collar using the Soil Moisture Probe with ThetaProbe moisture sensor (ML3PR2, Delta-T, UK) and temperature sensors (KM330, Comark Instuments, UK) (Noe et al. 2015) from the Norway spruce and mixed stands $(n=2-4)$ in 2017 2018. We measured monthly litterfall using litter collectors from both forest stands at the SMEAR Estonia station, and from the Scots pine stand at the SMEAR II station.

Soil properties including carbon (C) and nitrogen (N) content and soil acidity $(\mathrm{pH})$ were determined for both forest stands at the SMEAR Estonia station, and from the Scots pine stand at the SMEAR II station were determined (Table 2). At the SMEAR II station, soil properties were determined for the O-, A-, and Bhorizons as the means of five locations and at the SMEAR Estonia station, as the means of three locations. Plant cover was estimated in July-August based on visual assessment by dividing vegetation into four categories, where the mean plant cover was $1-15 \%$ (I), 1645\% (II), 46-70\% (III) and 71-100\% (IV) of the soil collar area (Table 2).

Analytical methods

The VOC concentrations of the adsorbent tubes were analysed using a thermal desorption-gas chromatography-mass spectrometer (TD-GC-MS, PerkinElmer, Waltham, MA, United States). The adsorbent tubes were desorbed at $300^{\circ} \mathrm{C}$ for $5 \mathrm{~min}$. The compounds were then cryofocused at $-30{ }^{\circ} \mathrm{C}$ in a Tenax cold trap and injected into the gas-chromatograph column by heating the cold trap to $300{ }^{\circ} \mathrm{C}$ (Aaltonen et al. 2011; Mäki et al. 2017). The mass detector uses simultaneous full scan and selected ion monitoring. Four calibration standards of the different VOC concentrations in methanol solutions were used to calibrate the instrument. Calibration standards contained all the different monoterpenoids $(\alpha$ pinene, camphene, $\Delta$-3-carene, $\beta$-pinene, myrcene, 1,8-cineol, linalool, limonene, p-cymene and terpinolene), but for sesquiterpenes only longicyclene, isolongifolene, $\beta$-caryophyllene, $\alpha$-humulene, $\alpha$ gurjunene and $\beta$-farnesene were included in the standard solution. Due to lack of calibration standards for most of the sesquiterpenes ( $\alpha$-buinesene, $\gamma$-muurolene, $\alpha$-bisabolene, $\beta$-himachalene, $\alpha$-muurolene, $\Delta$ cadinene and SQT1), these were tentatively identified by their retention indexes and mass spectrums and quantitated by the responses of the known sesquiterpenes: $\beta$-caryophyllene, isolongifolene, or longicyclene. Lack of calibration standards for sesquiterpenes likely causes some bias for sesquiterpene quantification. One sesquiterpene could not be identified and was marked as SQT1. 
Statistical analyses

The non-parametric Kruskal-Wallis test was used with significance levels of $p<0.100\left({ }^{\circ}\right), p<0.050\left(^{*}\right)$, $p<0.010(* *)$, and $p<0.001$ (***) to determine whether the climate zone (boreal/hemiboreal) and the forest type (Scots pine/Norway spruce) had a significant effect on monoterpenoid and sesquiterpene flux rates from the forest floor $(n=6)$. Exponential regression of the total monoterpenoid and sesquiterpene fluxes with temperature and soil moisture were determined for each stand. The $\mathrm{R}^{2}$ and $p$ values $<0.1$ indicate the exponential regression was significant. Guenther algorithm $\left[\mathrm{t}_{\mathrm{E}}=\mathrm{E}_{\mathrm{S}}\right.$ $\left[\exp \left(\beta\left(T-T_{s}\right)\right)\right]$ was used to calculate the emission potentials i.e. normalized emission rates $\left(E_{0}, \mu \mathrm{g}\right.$ $\mathrm{m}^{-2} \mathrm{~h}^{-1}$ ) in $30{ }^{\circ} \mathrm{C}$ (Guenther et al. 1993) for each compound.

The comparison between the two sites, differing by climate and by current forest vegetation, allows a simple comparative analysis of the long-term effects of climate change on forest floor emissions at landscape level. This accounts for the potential long-term impacts of changing tree species distribution (e.g. Kellomäki et al. 2008) and biomass density changes, but not the immediate impacts of soil moisture or temperature. The percentage of broadleaf trees and mixed forests is predicted to increase considerably in the southern parts of the country, and the dominance of spruce will decrease especially in Southern Finland. Changes in the geographic distribution of conifers may also affect forest floor vegetation, litter production (both quantity and quality) and carbon and nitrogen pools (Hansson et al. 2011, 2013a, b), and consequently also the main sources of forest floor VOCs.

\section{Results}

Conditions at the measurement sites

The daily mean temperatures showed very similar temporal dynamics between the SMEAR II station and the SMEAR Estonia station (Fig. 2). The median difference between the SMEAR II and SMEAR Estonia temperatures was $1.6{ }^{\circ} \mathrm{C}$, with slightly higher temperatures observed at SMEAR Estonia. Water holding capacity was highest in the hemiboreal mixed stand (0.08$0.90 \mathrm{~m}^{3} \mathrm{~m}^{-3}$ ), second highest in the hemiboreal Norway spruce stand $\left(0.06-0.69 \mathrm{~m}^{3} \mathrm{~m}^{-3}\right)$ and lowest and most constant in the boreal Scots pine stand $(0.07-$ $0.45 \mathrm{~m}^{3} \mathrm{~m}^{-3}$ ) (Fig. 3). Soil water content in the boreal Norway spruce stand is likely very similar to the boreal Scots pine stand, because the stands are located next to each other on Haplic Podzol soil. Soil water content was lower in 2018 compared to 2017 at both stations. The cumulative mean litterfall was mostly highest and rather stable throughout the season in the hemiboreal mixed stand (May-Oct 2017: $347.1 \mathrm{~g}_{\mathrm{DW}} \mathrm{m}^{-2}$ and May-Aug 2018: $225.6 \mathrm{~g}_{\mathrm{DW}} \mathrm{m}^{-2}$ ). Litterfall varied more in the other stands and was the second highest in the boreal Pine stand (May-Oct 2017: $223.7 \mathrm{~g}_{\mathrm{DW}} \mathrm{m}^{-2}$ and MayAug 2018: $224.7 \mathrm{~g}_{\mathrm{DW}} \mathrm{m}^{-2}$ ), and lowest in the hemiboreal Norway spruce stand (May-Oct 2017: $154.7 \mathrm{~g}_{\mathrm{DW}} \mathrm{m}^{-2}$ and May-Aug 2018: $182.8 \mathrm{~g}_{\mathrm{DW}} \mathrm{m}^{-2}$ ) (Fig. 4). Litterfall was not measured from the boreal Norway spruce stand. Soil $\mathrm{pH}$ and carbon and nitrogen content were rather similar between the studied stands (Table 2).

VOC fluxes at different forest floor stands

The mean monoterpenoid flux rates were mainly similar between the boreal Scots pine and the hemiboreal mixed stands, but the difference in flux rates was statistically significant for p-cymene, 1,8-cineol, linalool, limonene and terpinolene (Table 3 ). The mean flux rates of $\alpha$ pinene, camphene, $\beta$-pinene, limonene and bornylacetate were higher from the boreal Norway spruce forest floor compared to the hemiboreal Norway spruce forest floor, while the opposite trend was observed for p-cymene, 1,8-cineol, terpinolene, linalool and myrcene. The mean flux rates of different sesquiterpenes were mainly similar between the studied stands, while the difference in flux rates was statistically significant for $\alpha$-gurjunene, SQT1, $\alpha$-bisabolene and $\beta$ himachalene.

The total mean monoterpenoid fluxes were higher from the boreal Scots pine forest floor (boreal $\left.23 \mu \mathrm{g} \mathrm{m}^{-2} \mathrm{~h}^{-1}, p<0.1^{\circ}\right)$ and from the hemiboreal mixed forest floor $\left(32 \mu \mathrm{g} \mathrm{m}^{-2} \mathrm{~h}^{-1}, p<0.01^{* *}\right)$ compared to the Norway spruce forest floor in boreal $\left(12 \mu \mathrm{g} \mathrm{m}^{-2} \mathrm{~h}^{-1}\right)$ and hemiboreal $\left(9 \mu \mathrm{g} \mathrm{m}^{-2} \mathrm{~h}^{-1}\right)$ climates (Table 3). The total mean sesquiterpene fluxes were also higher from the boreal Scots pine forest floor $\left(0.8 \mu \mathrm{g} \mathrm{m}^{-2} \mathrm{~h}^{-1}, \mathrm{p}<\right.$ $\left.0.1^{\mathrm{o}}\right)$ and from the hemiboreal mixed forest floor $\left(1.3 \mu \mathrm{g} \mathrm{m}^{-2} \mathrm{~h}^{-1}, p<0.05^{*}\right)$ compared to the Norway spruce forest floor in boreal $\left(0.5 \mu \mathrm{g} \mathrm{m}^{-2} \mathrm{~h}^{-1}\right)$ and hemiboreal $\left(0.6 \mu \mathrm{g} \mathrm{m}^{-2} \mathrm{~h}^{-1}\right)$ climates (Table 3). 


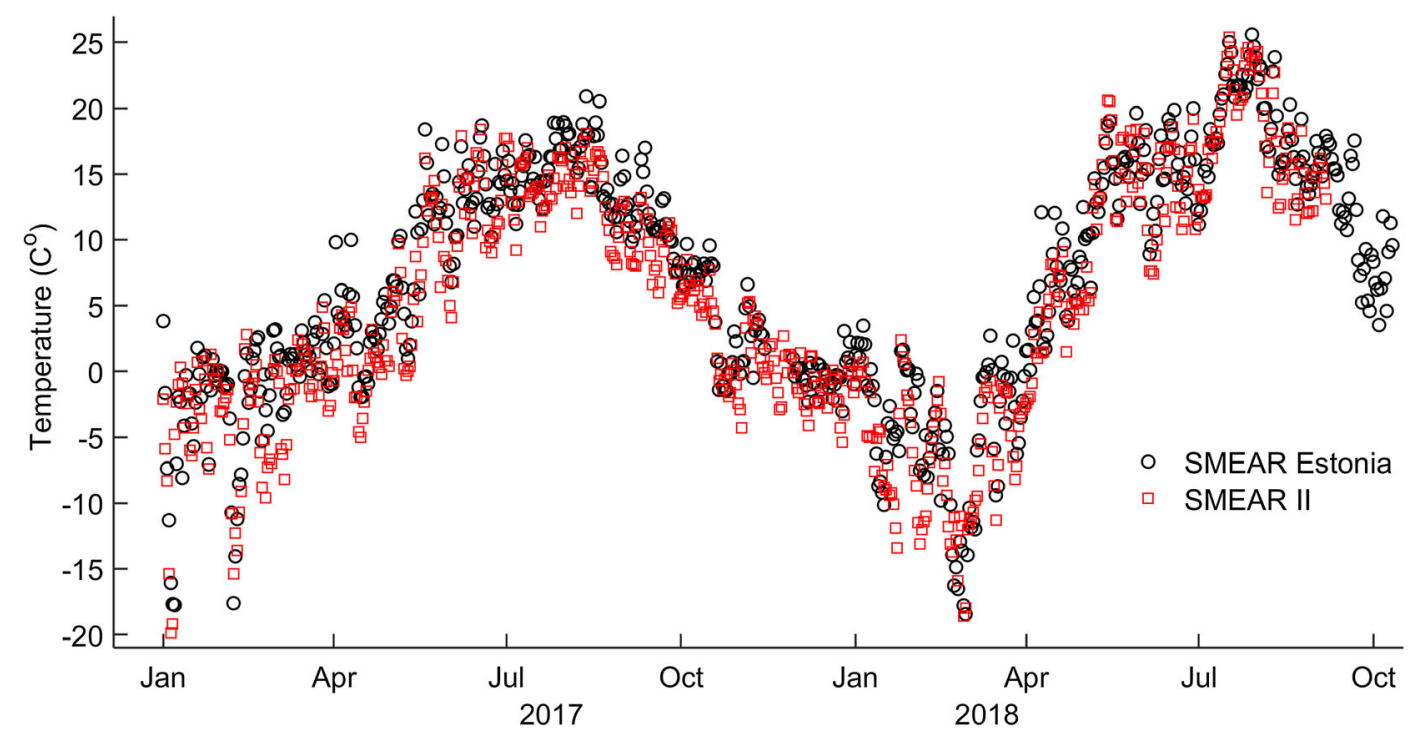

Fig. 2 Daily means of ambient temperature $\left({ }^{\circ} \mathrm{C}\right)$ during $2017-2018$ in the Scots pine stand at the SMEAR II station (8.4 $\mathrm{m}$ above ground) and in the mixed and the Norway spruce stands at the SMEAR Estonia station ( $2 \mathrm{~m}$ above ground)

Seasonal dynamics of VOC fluxes from the forest floor

The highest monoterpenoid and sesquiterpene fluxes were observed in spring and summer (May-August) in all the studied forest stands (Figs. 5 and 6). The highest monoterpenoid flux rates were observed from the boreal Scots pine forest floor in May and June and from the hemiboreal mixed forest floor in May, June and July. The monoterpenoid fluxes were also high from the boreal Norway spruce forest floor in July 2017 and in May and July in 2018 and from the hemiboreal Norway spruce forest floor in May 2017 and in August 2018. The total monoterpenoid fluxes from the boreal Scots pine forest floor decreased from June to July 2018 after a dry summer period (Fig. 5a), while the sesquiterpene fluxes increased further in higher chamber temperatures (28$30{ }^{\circ} \mathrm{C}$ ) (Fig. 6a). Sesquiterpene fluxes peaked from the hemiboreal forest floor in August 2018, when the chamber temperature was high $\left(16-29^{\circ} \mathrm{C}\right)$ (Fig. 6b). The total monoterpenoid fluxes from the hemiboreal mixed forest floor also peaked in October 2017 (Fig. 5b).

Chamber temperature explained $10-75 \%$ $\left(p<0.001^{* * *}\right)$ of the total monoterpenoid fluxes, except in the hemiboreal mixed stand (Fig. 7). Generally

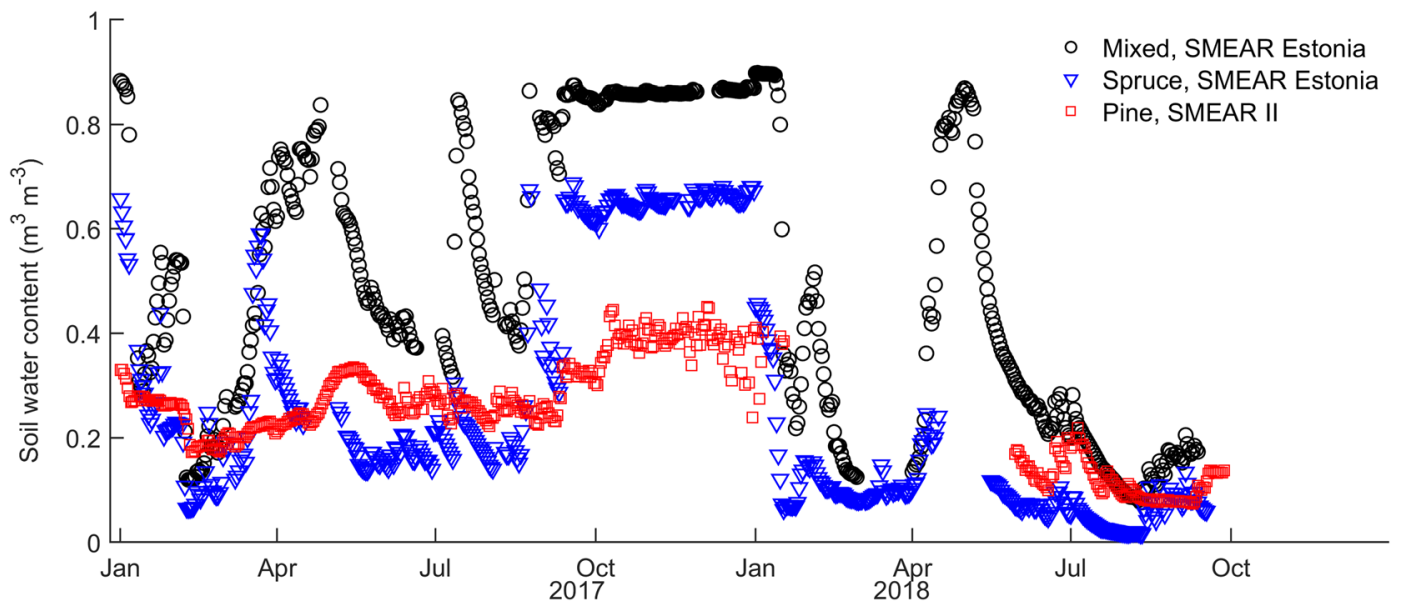

Fig. 3 Daily means of soil water content $\left(\mathrm{m}^{3} \mathrm{~m}^{-3}\right)$ during 2017-2018 from the Scots pine stand at the SMEAR II station $(n=5,14-25 \mathrm{~cm}$ depth) and from the mixed and the Norway spruce stands $(n=2-5,10-30 \mathrm{~cm}$ depth) at the SMEAR Estonia station 


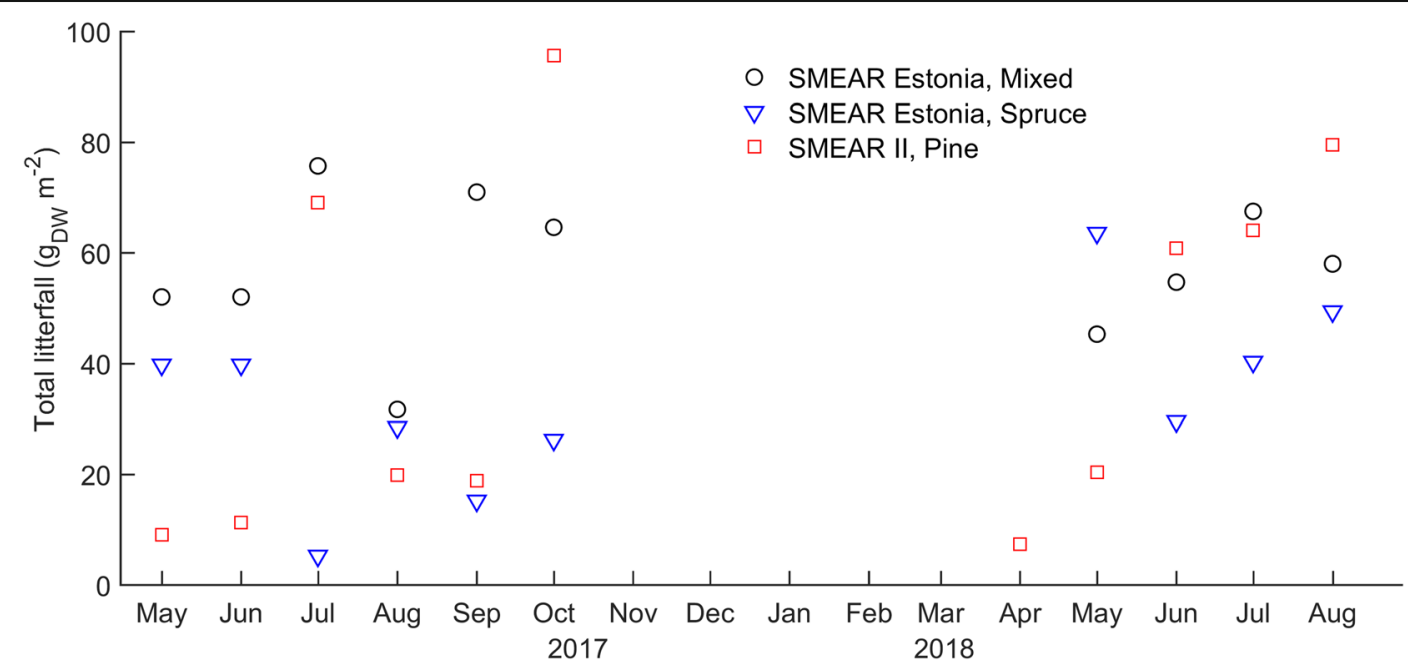

Fig. 4 The total monthly litterfall $\left(\mathrm{g}_{\mathrm{DW}} \mathrm{m}^{-2}\right.$ ) during $2017-2018$ from the Scots pine stand at the SMEAR II station and from the mixed and the Norway spruce stands at the SMEAR Estonia station

monoterpenoids showed stronger correlation with chamber temperature in the Norway spruce stands compared to the Scots pine and the mixed stands (Supplementary Table 1). Chamber temperature explained $32-61 \%$ $\left(p<0.001^{* * *}\right)$ of $\beta$-pinene, camphene, 1,8-cineol, limonene, and myrcene fluxes in the boreal Norway spruce stand and $81-93 \%\left(p<0.001^{* * *}\right)$ of $\Delta 3$-carene, 1,8 cineol, myrcene, terpinolene and linalool fluxes in the hemiboreal Norway spruce stand. Fluxes of 1,8-cineol, myrcene and p-cymene were also explained by chamber temperature $\left(35-72 \%, p<0.001^{* * *}\right)$ in the hemiboreal mixed stand.

Contrary to monoterpenoid fluxes, chamber temperature explained only $9-32 \%(p<0.001 * * *)$ of the total sesquiterpene fluxes, when all measurements were pooled (Fig. 8). However, individual sesquiterpenes showed better correlations with temperature. Longicyclene, $\alpha$-gurjunene, $\beta$-farnesene, $\alpha$-humulene and $\beta$-himachalene correlated with chamber temperature in the hemiboreal stands and longicyclene, $\alpha$ gurjunene, $\beta$-farnesene, aromadendrene, $\alpha$-muurolene and $\Delta$-cadinene in the boreal stands (Supplementary Table 1). Chamber temperature explained $20-77 \%$ (p $<0.001 * * *)$ of the variation of $\alpha$-gurjunene, $\beta$ himachalene, SQT1, $\alpha$-humulene and longicyclene fluxes from the hemiboreal mixed forest floor and 40$74 \%(p<0.05 *)$ of the variation of $\alpha$-humulene, $\beta$ farnesene and longicyclene fluxes from the hemiboreal Norway spruce forest floor. Chamber temperature also explained $24-62 \%\left(p<0.05^{*}\right)$ of the variation of longicyclene, $\alpha$-gurjunene, $\beta$-farnesene, aromadendrene, $\alpha$-muurolene and $\Delta$-cadinene fluxes from the boreal Scots pine forest floor and $27 \%$ $(p<0.001 * * *)$ of the variation of $\Delta$-cadinene from the boreal Norway spruce forest floor (Supplementary Table 1). Normalized emission rates $\left(E_{0}, \mu \mathrm{g} \mathrm{m}^{-2} \mathrm{~h}^{-1}\right)$ in $30^{\circ} \mathrm{C}$ (Guenther et al. 1993) were also calculated for each compound (Supplementary Table 1).

In general, the variation of the total monoterpenoid and sesquiterpene fluxes from forest floors in the boreal sites was not correlated with soil moisture. However, in the hemiboreal Norway spruce stand, the total monoterpenoid fluxes from the forest floor decreased when soil moisture increased and soil moisture explained $24-72 \%(p<0.01 * *)$ of the variation of some monoterpenoids, including 1,8-cineol, camphene, $\Delta 3$ carene, myrcene, linalool, terpinolene and p-cymene. As the Norway spruce site was highly heterogenic with moist pits and drier mounds, the effect of soil moisture on the total monoterpenoid fluxes was also compared separately on mound surfaces with lower soil moisture $\left(\mathrm{R}^{2}=0.99, p<0.001^{* * *}\right)$ and on the pit surfaces with higher soil moisture $\left(\mathrm{R}^{2}=0.89, p<0.001 * * *\right)$ (Fig. 9b). Although in the hemiboreal mixed forest floor there was no correlation between the total monoterpenoid fluxes and soil moisture (Fig. 9a), soil moisture still explained $44-68 \%(p<0.001 * * *)$ of the variation of 1,8 -cineol, myrcene and p-cymene from the hemiboreal mixed forest floor (Supplementary Table 2).

Soil moisture explained $47-52 \%\left(p<0.001^{* * *}\right)$ of the hemiboreal Norway spruce forest floor (Fig. 10), and also $11-46 \%(p<0.001 * * *)$ of the hemiboreal mixed 
Table 3 The mean for monoterpernoid and sesquiterpene fluxes $\left(\mu \mathrm{g} \mathrm{m}^{-2} \mathrm{~h}^{-1}\right)$ from Scots pine and Norway spruce forest floors at the SMEAR II station (boreal) and the SMEAR Estonia station (hemiboreal) from 2017 to 2018

\begin{tabular}{|c|c|c|c|c|}
\hline \multirow[t]{2}{*}{ Flux } & \multicolumn{2}{|l|}{ SMEAR II } & \multicolumn{2}{|c|}{ SMEAR Estonia } \\
\hline & Pine stand & Spruce stand & Mixed stand & Spruce stand \\
\hline \multicolumn{5}{|l|}{ Monoterpenoids } \\
\hline$\alpha$-pinene & $12.4^{\mathrm{a}}(8.5)$ & $4.4^{\mathrm{b}}(2.0)$ & $\mathbf{2 1 . 1}^{\mathrm{a}}(6.5)$ & $2.3^{\mathrm{c}}(4.4)$ \\
\hline camphene & $1.9^{\mathrm{a}}(0.8)$ & $2.6^{\mathrm{a}}(1.3)$ & $2.6^{\mathrm{a}}(0.7)$ & $0.7^{\mathrm{b}}(0.3)$ \\
\hline$\beta$-pinene & $0.6^{\mathrm{a}}(0.6)$ & $1.2^{\mathrm{b}}(0.7)$ & $0.8^{\mathrm{ab}}(0.19)$ & $0.37^{\mathrm{c}}(0.51)$ \\
\hline$\Delta 3$-carene & $8.4^{\mathrm{a}}(6.1)$ & $1.8^{\mathrm{b}}(1.1)$ & $8.7^{\mathrm{a}}(0.7)$ & $2.7^{\mathrm{b}}(1.6)$ \\
\hline p-cymene & $0.3^{\mathrm{a}}(0.1)$ & $0.2^{\mathrm{b}}(0.02)$ & $0.8^{\mathrm{c}}(0.3)$ & $17.4^{\mathrm{d}}(10.3)$ \\
\hline 1,8-cineol & $0.02^{\mathrm{a}}(0.002)$ & $0.3^{\mathrm{b}}(0.1)$ & $0.31^{\mathrm{b}}(0.1)$ & $\mathbf{0 . 7 ^ { \mathrm { c } }}(0.4)$ \\
\hline limonene & $0.5^{\mathrm{a}}(0.4)$ & $2.6^{\mathrm{b}}(1.1)$ & $1.9^{\mathrm{b}}(0.5)$ & $0.5^{\mathrm{a}}(0.3)$ \\
\hline terpinolene & $0.1^{\mathrm{a}}(0.1)$ & $0.02^{\mathrm{b}}(0.004)$ & $\mathbf{0 . 2 ^ { \mathrm { c } }}(0.1)$ & $0.1^{\mathrm{a}}(0.1)$ \\
\hline linalool & $0.5^{\mathrm{ac}}(0.7)$ & $0.2^{\mathrm{a}}(0.1)$ & $0.1^{\mathrm{b}}(0.1)$ & $\mathbf{0 . 8 ^ { \mathrm { c } }}(0.9)$ \\
\hline myrcene & $0.5^{\mathrm{a}}(0.4)$ & $1.0^{\mathrm{a}}(0.6)$ & $0.5^{\mathrm{a}}(0.1)$ & $4.6^{\mathrm{b}}(2.4)$ \\
\hline bornylacetate & $0.03^{\mathrm{a}}(0.01)$ & $0.1^{\mathrm{b}}(0.1)$ & $0.1^{\mathrm{a}}(0.1)$ & $0.03^{\mathrm{a}}(0.02)$ \\
\hline Sum of the monoterpenoids & $23.1(14.6)^{\mathrm{a}}$ & $11.5(5.2)^{\mathrm{b}}$ & $32.1(6.0)^{\mathrm{a}}$ & $9.1(6.0)^{\mathrm{b}}$ \\
\hline \multicolumn{5}{|l|}{ Sesquiterpenes } \\
\hline longicyclene & $0.01(0.01)$ & $\mathbf{0 . 0 2}(0.01)$ & $0.01(0.004)$ & $0.01(0.005)$ \\
\hline isolongifolene & 0.01 & 0.2 & $0.03(0.02)$ & $\mathrm{BDL}$ \\
\hline$\alpha$-gurjunene & $0.4^{\mathrm{a}}(0.1)$ & $0.1^{\mathrm{b}}(0.03)$ & $0.2^{\mathrm{ab}}(0.3)$ & $1.9^{\mathrm{c}}(0.7)$ \\
\hline$\beta$-farnesene & $0.2^{\mathrm{a}}(0.2)$ & $0.2^{\mathrm{a}}(0.1)$ & $0.1^{\mathrm{b}}(0.1)$ & $0.1(0.03)$ \\
\hline$\beta$-caryophyllene & $\mathbf{0 . 3 ^ { \mathrm { a } }}(0.2)$ & $0.2(0.1)$ & $0.2^{\mathrm{a}}(0.1)$ & $0.1^{\mathrm{b}}(0.04)$ \\
\hline aromadendrene & $0.1(0.02)$ & $0.1(0.1)$ & $0.1(0.04)$ & 0.3 \\
\hline$\alpha$-humulene & $\mathbf{0 . 0 4}(0.02)$ & $0.02^{\mathrm{a}}(0.01)$ & $\mathbf{0 . 0 4}{ }^{\mathrm{b}}(0.02)$ & $0.03(0.02)$ \\
\hline SQT1 & $0.1^{\mathrm{a}}(0.1)$ & $0.04^{\mathrm{b}}(0.03)$ & $6.3^{\mathrm{c}}(4.8)$ & $1.3^{\mathrm{ab}}(2.5)$ \\
\hline$\alpha$-curcumene & $\mathbf{0 . 1}{ }^{\mathrm{a}}(0.04)$ & $0.1^{\mathrm{a}}(0.02)$ & $0.02^{\mathrm{b}}(0.01)$ & $\mathrm{BDL}$ \\
\hline$\alpha$-buinesene & $\mathbf{0 . 1}^{\mathrm{a}}(0.03)$ & $0.1^{\mathrm{a}}(0.1)$ & $\mathbf{0 . 1}{ }^{\mathrm{a}}(0.04)$ & $0.02^{\mathrm{b}}(0.01)$ \\
\hline$\gamma$-muurolene & $\mathbf{0 . 0 4}{ }^{\mathrm{a}}(0.02)$ & $0.03(0.02)$ & $0.02^{\mathrm{b}}(0.01)$ & $0.02^{\mathrm{b}}(0.01)$ \\
\hline$\alpha$-bisabolene & $\mathbf{0 . 1} \mathbf{1}^{\mathrm{a}}(0.04)$ & $0.04^{\mathrm{b}}(0.02)$ & $0.1^{\mathrm{c}}(0.04)$ & $0.1^{\mathrm{bc}}(0.1)$ \\
\hline$\beta$-himachalene & $0.1^{\mathrm{ab}}(0.02)$ & $0.04^{\mathrm{a}}(0.02)$ & $0.1^{\mathrm{b}}(0.05)$ & $\mathbf{0 . 3 ^ { \mathrm { c } }}(0.1)$ \\
\hline$\alpha$-muurolene & $\mathbf{0 . 1}^{\mathrm{a}}(0.03)$ & $0.1(0.1)$ & $0.05^{\mathrm{a}}(0.02)$ & $0.03^{\mathrm{b}}(0.05)$ \\
\hline$\Delta$-cadinene & $\mathbf{0 . 3 ^ { \mathrm { a } }}(0.1)$ & $0.2^{\mathrm{a}}(0.2)$ & $0.2^{\mathrm{a}}(0.1)$ & $0.1^{\mathrm{b}}(0.1)$ \\
\hline Sum of the sesquiterpenes & $0.9(0.3)^{\mathrm{a}}$ & $0.5(0.4)^{\mathrm{bc}}$ & $\mathbf{1 . 3}(1.2)^{\mathrm{ac}}$ & $0.6(0.6)^{b}$ \\
\hline
\end{tabular}

The mean flux rates with standard deviation are means of six soil collars for each measurement site and the flux rate of each soil collar is an average over the full measurement period. Significant differences in fluxes between the forest stands are marked with different letters ( $a$, $b$, and $\mathrm{c} p<0.1^{\mathrm{o}}$ ). BDL $=$ below detection limit of the VOC quantification. The highest value is highlighted in bold

forest floor total sesquiterpene fluxes, and was significant contributor in fluxes from both mounds and pits. Soil moisture also explained $32-45 \%\left(p<0.05^{*}\right)$ of the variation of some sesquiterpenes, including $\alpha$ gurjunene and $\alpha$-humulene from the hemiboreal Norway spruce forest floor and $34-36 \%(p<0.05 *)$ of the variation of $\alpha$-gurjunene and longicyclene from the hemiboreal mixed forest floor (Supplementary Table 2).

\section{Discussion}

Climate and stand type affects forest floor VOC fluxes

This study is the first one to compare forest floor monoterpene and sesquiterpene fluxes between stands differing in climate region and stand composition, and provides evidence that the forest floor VOC fluxes from 
Fig. 5 Seasonal patterns in mean monoterpenoid fluxes ( $\mu \mathrm{g} \mathrm{m}^{-2} \mathrm{~h}^{-1}$ ) during 2017-2018 from a the boreal Scots pine and the Norway spruce stands at the SMEAR II station and $\mathbf{b}$ from the hemiboreal mixed and the Norway spruce stands at the SMEAR Estonia station. Error bars show standard deviation $(n=5$ or 6$)$

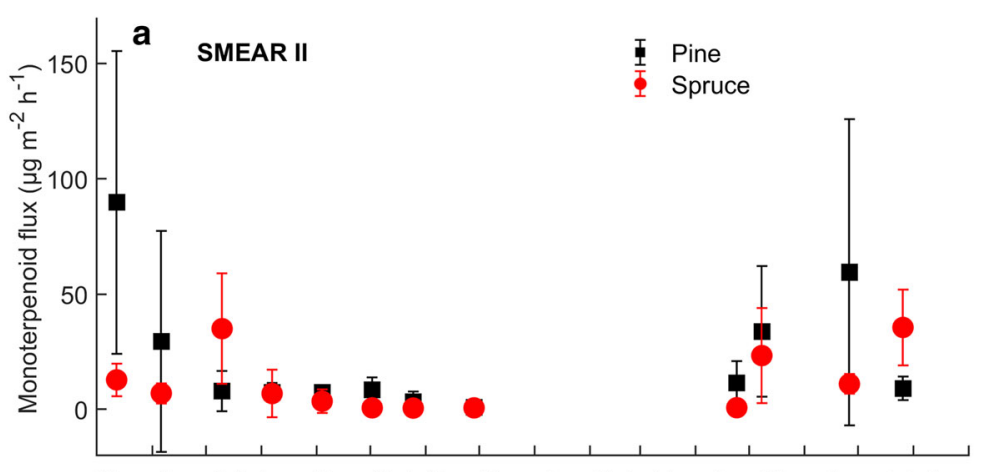

May Jun Jul Aug Sep Oct Nov Dec Jan Feb Mar Apr May Jun Jul Aug

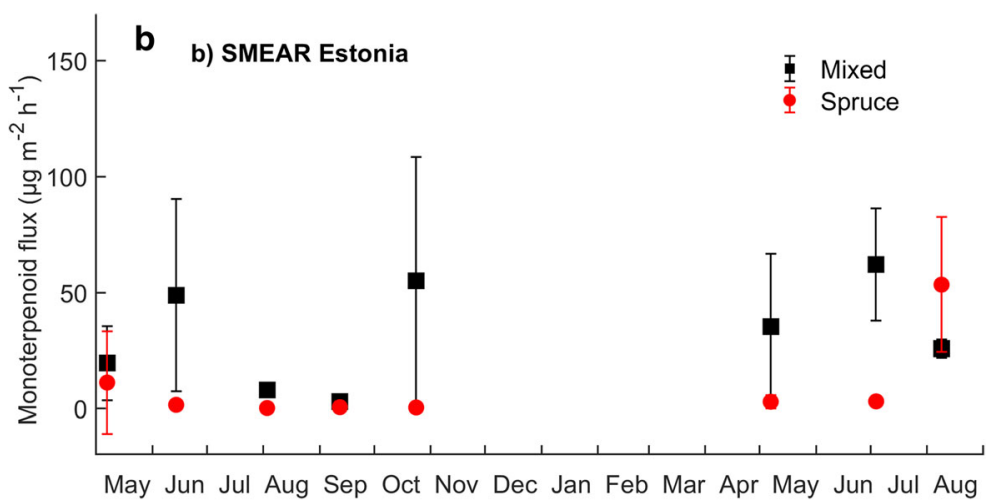

conifer-dominated ecosystems vary a lot with stand type, tree species and climate. There may be several reasons for the differences. A likely one is the longer growing season and higher temperatures in more southern, hemiboreal ecosystems, increasing the total VOC production and release from forest floor and soil. This was seen in this study, where the hemiboreal mixed forest floor was the largest VOC source compared to the boreal pine or spruce. However, the climatic effect was not consistent across all stands, and the Norway spruce forest floor was a greater source for several monoterpenoids in the boreal climate compared to the hemiboreal climate. This indicates that also the stand composition has a significant effect on VOC fluxes.

Overall, the measured total mean monoterpenoid fluxes from forest floor $\left(9-32 \mu \mathrm{g} \mathrm{m}^{-2} \mathrm{~h}^{-1}\right.$ for the different stands, Table 3) were comparable to earlier studies from boreal forest (4-40 $\mu \mathrm{g} \mathrm{m}^{-2} \mathrm{~h}^{-1}$; Aaltonen et al. 2011, 2013; Mäki et al. 2017, 2019). Significantly higher fluxes were occasionally measured by Hellén et al. (2006) and Janson (1993), likely reasons for these high numbers are monoterpene fluxes from decomposing litter after snowmelt and after fresh litterfall release in autumn. Normalized emission rates for monoterpenes from a Sitka spruce forest soil (Hayward et al. 2001: $34 \mu \mathrm{g} \mathrm{m}^{-2} \mathrm{~h}^{-1}$ ) were also at the same magnitude as in our study (42$123 \mu \mathrm{g} \mathrm{m}^{-2} \mathrm{~h}^{-1}$ ) (Supplementary Table 1). The total monoterpene fluxes in our study were higher than those in arctic and temperate climates, such as subarctic heath (Faubert et al. 2010: 1.5-9.8 $\mathrm{gg} \mathrm{m}^{-2} \mathrm{~h}^{-1}$ ), high Arctic Salix-heath (Lindwall et al. 2015: $0.01 \mu \mathrm{g} \mathrm{m}^{-2} \mathrm{~h}^{-1}$ ), high Arctic Cassiope-heath (Lindwall et al. 2015: $7 \mu \mathrm{g} \mathrm{m}^{-2} \mathrm{~h}^{-1}$ ), and temperate Deschampsia flexuosa heath (Rinnan et al. 2013: $0.05 \mu \mathrm{g} \mathrm{m}^{-2} \mathrm{~h}^{-1}$ ). Together, these studies show that although northern soils are a significant monoterpene source, monoterpene flux rates vary between ecosystems or even within an ecosystem type.

The total mean sesquiterpene fluxes from boreal and hemiboreal forest floors $\left(0.5-1.3 \mu \mathrm{g} \mathrm{m}^{-2} \mathrm{~h}^{-1}\right.$ for the different stands, Table 3 ) were mainly higher compared to earlier studies from boreal forest floors (0.004$0.35 \mu \mathrm{g} \mathrm{m}^{-2} \mathrm{~h}^{-1}$, Aaltonen et al. 2011; Mäki et al. 2017). However, sesquiterpene fluxes in this study were similar in magnitude to the sesquiterpene fluxes in arctic climates, such as in subarctic heath (Faubert et al. 2010: 2.7-3.4 $\mathrm{\mu g} \mathrm{m}^{-2} \mathrm{~h}^{-1}$ ), subarctic heath with evergreen and 

sesquiterpene fluxes $\left(\mu \mathrm{g} \mathrm{m}^{-2} \mathrm{~h}^{-1}\right)$ from 2017 to 2018 for a the boreal Scots pine and the Norway spruce stands at the SMEAR II station and from $\mathbf{b}$ the hemiboreal mixed and the Norway spruce stands at the SMEAR Estonia station. Error bars show standard deviation $(n=$ 5 or 6 )
Fig. 6 Seasonal patterns in mean
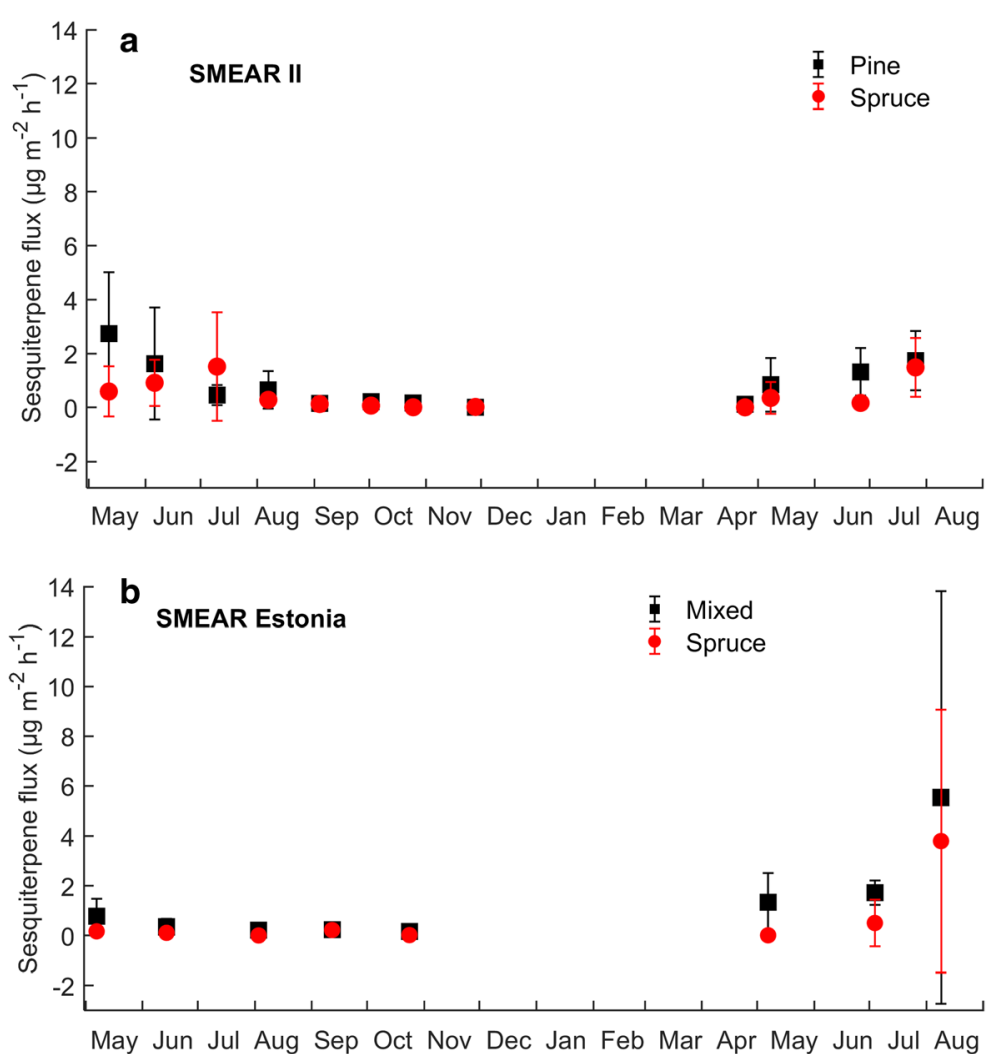

deciduous dwarf shrubs (Rinnan et al. 2013: $4 \mu \mathrm{g} \mathrm{m}^{-2} \mathrm{~h}^{-1}$ ), high arctic Cassiope-heath (Lindwall et al. 2015: $0.15 \mu \mathrm{g} \mathrm{m}^{-2} \mathrm{~h}^{-1}$ ), low arctic Betula-heath (Lindwall et al. 2015: $7 \mu \mathrm{g} \mathrm{m}^{-2} \mathrm{~h}^{-1}$ ), and in low arctic Salix-heath (Lindwall et al. 2015: $1 \mu \mathrm{g} \mathrm{m}^{-2} \mathrm{~h}^{-1}$ ). These studies show that sesquiterpene flux rates vary strongly depending on the prevailing vegetation type, which was also clear in our study.

VOC sources likely differ between the studied stands. Ground vegetation of the boreal forest floor was covered by Vaccinium spp. and mosses, which release isoprene, monoterpenes, sesquiterpenes, and oxygenated VOCs (Hanson et al. 1999; Hellén et al. 2006; Aaltonen et al. 2011; Faubert et al. 2012; Mäki et al. 2019), while the hemiboreal forest floor was open or covered by mosses that mostly emit isoprene and oxygenated VOCs (Hanson et al. 1999; Hellén et al. 2006). Tree roots were also a likely source of VOCs from the hemiboreal forest floor with high water content, because short-term flooding and increasing soil water content was found to enhance isoprenoid release from trees (see e.g. BrachoNunez et al. 2012; Bourtsoukidis et al. 2014b).
Dense ground vegetation cover of Vaccinium spp. and mosses releases VOCs in boreal stands, but forest floor vegetation may also be a monoterpene sink (Mäki et al. 2017), when monoterpenes are absorbed on the cuticle layer of leaves (Joensuu et al. 2016). However, ground vegetation was scanty under the dense tree canopy in the hemiboreal forest floor and for this reason, a monoterpene sink effect on net VOC flux was likely small, leading to higher monoterpenoid and sesquiterpene fluxes from the hemiboreal mixed forest floor.

The large stand biomass in the hemiboreal mixed stand, accompanied with higher leaf litter production and thus high quantities of monoterpenes from decaying storages during litter decomposition (Kainulainen and Holopainen 2002) very likely contributes to differences in emissions between the stands. This is supported by earlier studies performed in-situ and in the laboratory. Tree species have been shown to affect forest floor VOC fluxes, because litter decomposition is a large source of VOCs (Hayward et al. 2001; Greenberg et al. 2012). In the mixed hemiboreal stand, birches were 


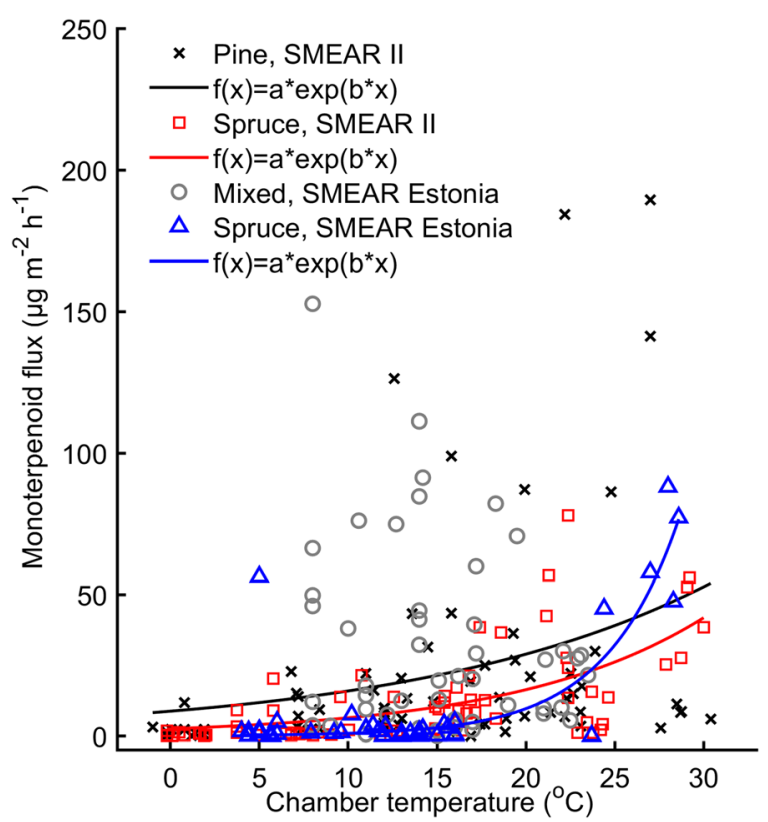

Fig. 7 Relationship between the total monoterpenoid fluxes $\left(\mu \mathrm{g} \mathrm{m}^{-2} \mathrm{~h}^{-1}\right)$ and chamber temperature $\left({ }^{\circ} \mathrm{C}\right)$ in the boreal Scots pine $\left(\mathrm{R}^{2}=0.10, p<0.001 * * *\right)$ and the Norway spruce stands $\left(\mathrm{R}^{2}=0.39, p<0.001^{* * *}\right)$ at the SMEAR II station and in the hemiboreal mixed $(p>0.1)$ and the Norway spruce stands $\left(\mathrm{R}^{2}=\right.$ $0.75, p<0.001 * * *)$ at the SMEAR Estonia station in 2017-2018. The $\mathrm{R}^{2}$ and $p$ values indicate the exponential correlation was significant for SMEAR II

abundant (Betula pendula and B. pubescens, 55\% of the forest cover), and their leaves were also present in the soil collars of the boreal Norway spruce stand. Birch leaves decompose faster than needles (Cornwell et al. 2008) due to substrate lability that accelerates microbial activity (Leff and Fierer 2008), which may increase VOC fluxes from the hemiboreal mixed forest floor as well as from the boreal Norway spruce forest floor. Further, Isidorov et al. (2010), observed that monoterpene flux rates from Scots pine litter were from five to nearly ten times higher compared to Norway spruce during the first 77 days of litter decomposition, and also Smolander et al. (2006) found higher monoterpene concentrations in soil air beneath pine canopies compared to spruce canopies. Sesquiterpene fractions have been found to be larger in pine needles $(\sim 34 \%)$ compared to spruce needles $(\sim 11 \%)$ (Isidorov et al. 2003), supporting our finding that the pine forest floor and the mixed forest floor were higher sesquiterpene sources than the spruce forest floor in both climates.

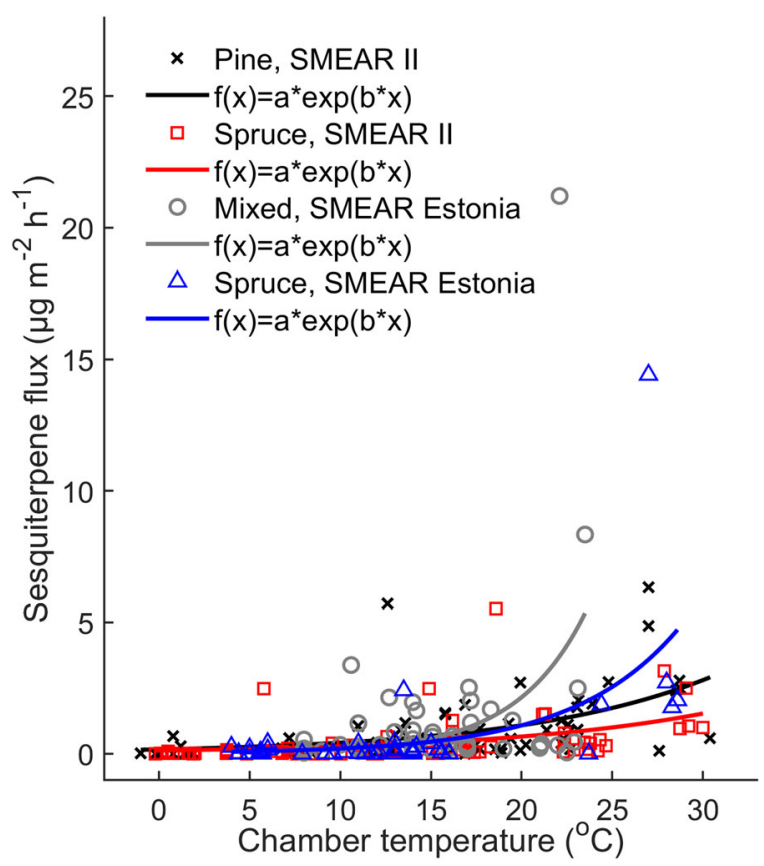

Fig. 8 Relationship between the total sesquiterpene fluxes $\left(\mu \mathrm{g} \mathrm{m}^{-2} \mathrm{~h}^{-1}\right)$ and chamber temperature $\left({ }^{\circ} \mathrm{C}\right)$ in the boreal Scots pine $\left(\mathrm{R}^{2}=0.11, p<0.001 * * *\right)$ and the Norway spruce stands $\left(\mathrm{R}^{2}=0.09, p<0.001^{* * *}\right)$ at the SMEAR II station and in the hemiboreal mixed $\left(\mathrm{R}^{2}=0.16, p<0.001 * * *\right)$ and the Norway spruce stands $\left(\mathrm{R}^{2}=0.32, p<0.001 * * *\right)$ at the SMEAR Estonia station in 2017-2018. The $\mathrm{R}^{2}$ and $\mathrm{p}$ values indicate the regression was significant in SMEAR II

It is important to note that VOC production rates may differ between laboratory studies and field measurements, because temperature, moisture and vegetation may cause more variation in the field (Leff and Fierer 2008). Isidorov et al. (2010) observed a larger difference in isoprenoid flux rates between Scots pine and Norway spruce litter in the laboratory than we observed in situ from the forest floor of Scots pine and Norway spruce stands in this study. In-situ VOC flux rates may also vary due to different microbial communities metabolising species-specific VOCs (Isidorov et al. 2016) at different forest stands. Soil microbial communities were found to differ between Pinus sylvestris, Picea abies and Betula pendula stands (Priha et al. 2001). The varying VOC flux rates between the stands could also be explained by a significant effect of the microbial community such as the VOC production and degradation (Bäck et al. 2010) and the soil organic matter content (Cederlund et al. 2014). According to Ramirez et al. (2010), litter emitted VOCs stimulated microbial respiration activity in soil. In several studies, 


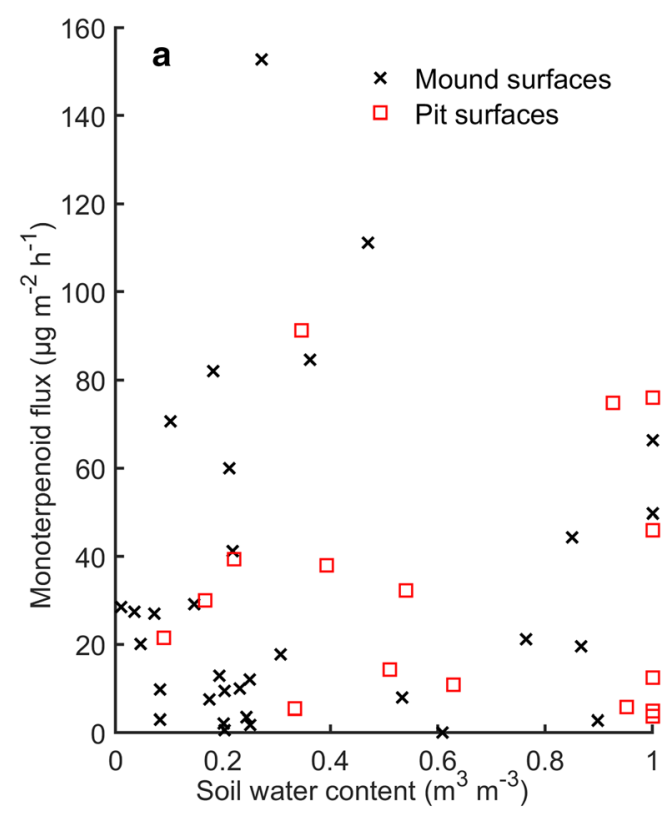

Fig. 9 Relationship between the total monoterpenoid fluxes $\left(\mu \mathrm{g} \mathrm{m}^{-2} \mathrm{~h}^{-1}\right.$ ) and soil water content $\left(\mathrm{m}^{3} \mathrm{~m}^{-3}\right)$ in the hemiboreal a mixed and $\mathbf{b}$ the Norway spruce forest floor at the SMEAR Estonia station for 2017-2018. The $\mathrm{R}^{2}$ and $\mathrm{p}$ values show significant exponential correlation. The results from the hemiboreal

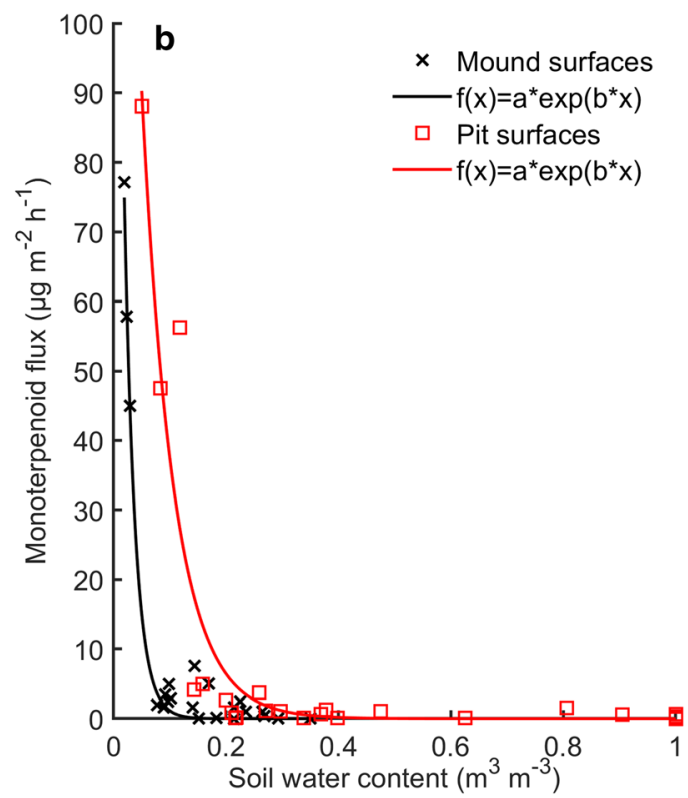

mixed forest floor are from two soil collars positioned on pit surfaces $(n=2)$ and four on mound surfaces $(n=4)$; results from the hemiboreal Norway spruce forest floor are from three soil collars positioned on pit surfaces $\left(n=3, \mathrm{R}^{2}=0.89, p<0.001 * * *\right)$ and three on mound surfaces $\left(n=3, \mathrm{R}^{2}=0.99, p<0.001 * * *\right)$

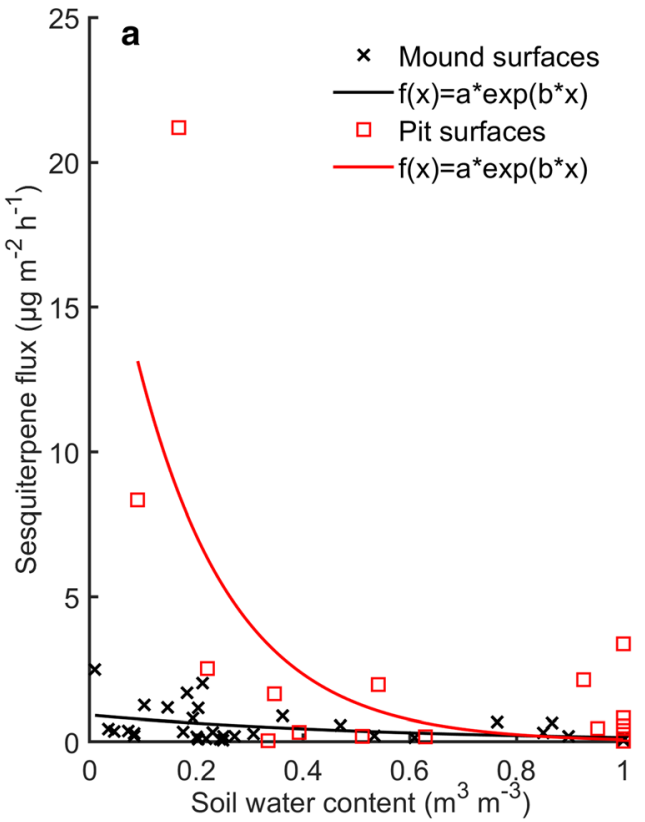

Fig. 10 Relationship between the total sesquiterpene fluxes $\left(\mu \mathrm{g} \mathrm{m}^{-2} \mathrm{~h}^{-1}\right)$ from forest floor and soil water content $\left(\mathrm{m}^{3} \mathrm{~m}^{-3}\right)$ in the hemiboreal a mixed and $\mathbf{b}$ the Norway spruce stands at the SMEAR Estonia station for 2017-2018. The $\mathrm{R}^{2}$ and $\mathrm{p}$ values indicate that the exponential correlation was significant. The results from the hemiboreal mixed forest floor are from two soil

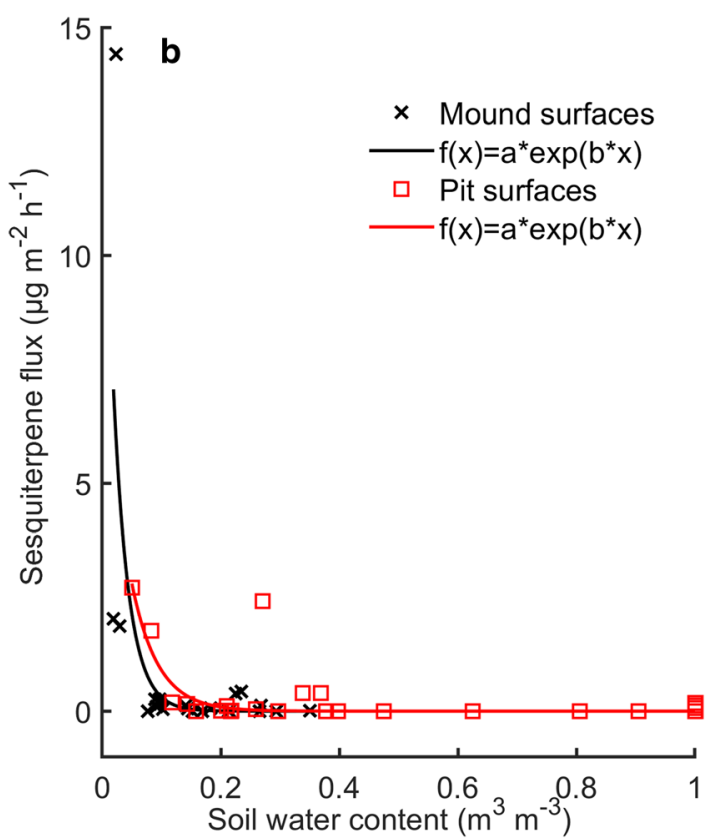

collars positioned on pit surfaces $\left(n=2, \mathrm{R}^{2}=0.46, p<0.001^{* * *}\right)$ and four on mound surfaces $\left(n=4, \mathrm{R}^{2}=0.11, p<0.001 * * *\right)$; results from the hemiboreal Norway spruce forest floor are from three soil collars positioned on pit surfaces $\left(n=3, \mathrm{R}^{2}=0.52\right.$, $\left.p<0.001^{* * *}\right)$ and three on mound surfaces $\left(n=3, \mathrm{R}^{2}=0.47\right.$, $p<0.001 * * *)$ 
the activity of carbon and net nitrogen mineralization was higher in spruce stands compared to pine stands (Priha et al. 2001; Kanerva and Smolander 2007; Smolander and Kitunen 2011). Additionally, higher VOC uptake of microbes in the spruce forest floor could also explain higher VOC fluxes from the boreal Scots pine forest floor and from the hemiboreal mixed forest floor compared to the spruce forest floors.

\section{Seasonal dynamics of forest floor VOC fluxes}

Isoprenoid fluxes followed a rather similar seasonal dynamic across the different forest stands. Monoterpenoid and sesquiterpene flux rates from the forest floor were generally highest in spring and summer, correlating with the period when new biomass production of ground vegetation occurred and microbial activity was likely high due to rising temperatures. Our results are supported by earlier studies, where forest floor monoterpene fluxes were found to be higher in spring and sesquiterpene fluxes in summer (Hellén et al. 2006; Mäki et al. 2017). High sesquiterpene release from the forest floor in summer likely ordinates from intensive root growth and root interactions with soil organisms (Ditengou et al. 2015). The high fluxes in spring are likely caused by decomposing litter and growth of forest floor vegetation (Hellén et al. 2006; Aaltonen et al. 2011). Coniferous roots store and release isoprenoids (Hayward et al. 2001; Lin et al. 2007). Abiotic mechanisms including VOC adsorption on clay particles and litter degradation through thawing-freezing and drying-wetting cycles may also affect forest floor VOC fluxes (Asensio et al. 2007a, b; 2008; Insam and Seewald, 2010; Deng et al. 2017). Soil clay content was high in hemiboreal stands (Noe et al. 2011).

When the forest floor and soil emissions are compared with aboveground emissions measured at the same stands, similarities in seasonal patterns are found. At our boreal pine site, Scots pine shoots release the highest monoterpene fluxes from May to August, and sesquiterpene fluxes from June to August (Hakola et al. 2009). Monoterpene flux rates from boreal Norway spruce shoots adjacent to our measurement site are also highest from June to August and sesquiterpene flux rates in July (Hakola et al. 2017). This is in accordance with the results in this study, indicating that, at the ecosystem scale, it is difficult to separate the forest floor emissions from the canopy emissions since they occur at same temporal dynamics. The importance of forest floor to whole stand VOC fluxes was significant, but strongly dependent on the season (Mäki et al. 2019). Forest floor monoterpene and methanol fluxes cover about 1-20\% of the forest stand fluxes in summer (Mäki et al. 2019). The effect of forest floor increases in spring and autumn and ranges from few percent up to $90 \%$ for monoterpenes and from a few per cent up to over $100 \%$ for methanol (Mäki et al. 2019). These results are supported by other study, where litter-released VOCs covered under $1 \%$ of the canopy fluxes in summer in a Ponderosa pine stand (Greenberg et al. 2012) and by other studies, where the Scots pine forest floor released from a few per cent to $40 \%$ of the canopy fluxes, when measurements were performed from spring to autumn (Janson 1993; Aaltonen et al. 2013).

It has been previously shown that the time of maximum litter production coincides with high forest floor emissions (e.g. Aaltonen et al. 2011; Mäki et al. 2017; Wang et al. 2018). In this study, the result was not so clear, and positive correlations between emissions and litter quantities were not seen. Litter decomposition is typically a high VOC source during the early decomposition phase (Isidorov et al. 2005), i.e. when the litter is fresh. Abiotic processes, such as mechanical decaying due to freezing-thawing events and photo- and thermochemical reactions, may also release VOCs (Cho et al. 2005; Fall et al. 2001; Warneke et al. 1999), especially in spring and autumn when temperatures vary greatly between day and night. The lack of correlations may reflect the large heterogeneity of the below-canopy processes affecting emissions: even though litter production at stand level can be high (as in our boreal SMEAR II site in October 2017), the probability that the litter actually falls on the six collars and increases the emissions is still quite low. Further, in the hemiboreal stand the litterfall quantity was quite stable throughout the summer, but emissions varied according to some other factors. Detailed experiments would be needed in order to verify the magnitude and regulating factors in litter-originating emissions.

The main physical factors influencing isoprenoid fluxes from forest floor and soil are temperature and soil moisture. Temperature correlated rather well with forest floor monoterpenoid and sesquiterpene fluxes in other stands than in the mixed forest, agreeing with earlier 
studies (Aaltonen et al. 2013; Mäki et al. 2017, 2019). It is well known that temperature promotes plant VOC biosynthesis (Kesselmeier and Staudt 1999) as well as accelerates compound volatilization (Guenther et al. 1993) and microbial activity that produces VOCs (Isidorov et al. 2016), and these factors are likely the main reasons for the temperature response of VOC fluxes from the forest floor in this study as well. The effect of soil moisture on forest floor VOC exchange is highly complex, because increasing soil moisture may increase or decrease forest floor VOC exchange. Increasing soil moisture hinders gas diffusion in soil and volatilization from the soil surface, increases deposition of VOCs on soil surface and VOC leaching towards the bedrock, but it may also increase VOC synthesis or uptake of microbes and VOC release of trees (Cousins et al. 1999; Asensio et al. 2007a; Bracho-Nunez et al. 2012; Bourtsoukidis et al. 2014b; Zhong et al. 2014; Bourtsoukidis et al. 2018). Earlier studies confirm that forest floor VOC fluxes are affected by soil moisture in boreal forests (Aaltonen et al. 2011), in Mediterranean forest soils (Asensio et al. 2007a), in arctic habitats (Svendsen et al. 2016) and in tropical forest soils (Bourtsoukidis et al. 2018). Most of these studies focus on the effect of dry soils on VOC fluxes. VOC emissions may occur under very dry conditions despite a probably low decomposition rate due to stress responses of living tissues. In this study, the hemiboreal site had a large soil moisture gradient with dry mounds and very wet depressions, and this diversity was also affecting the VOC fluxes locally.

VOC fluxes from the hemiboreal forest floor decreased with increasing soil moisture, indicating that indeed the excess moisture can decrease emissions. The main effects of soil moisture are linked to microbial decomposition, VOC evaporation from the soil surface and gas diffusion in soil (Skopp et al. 1990; Davidson and Janssens 2006; Asensio et al. 2007b; Zhong et al. 2014; Som et al. 2017). High soil moisture may also increase microbial VOC uptake, similar as in Mediterranean soil (Asensio et al. 2007a). Rewetting after drought is generally known to boost soil emissions probably because of moisture-induced increase in microbial activity (Rossabi et al. 2018). The dryingwetting dynamic may also affect VOC biodegradation in soil (Cho et al. 2005), which may decrease VOC fluxes in high soil moisture. It is likely that both microbial decomposition and biodegradation play a role in soil VOC exchange and the composition of microbial community defines, which one of those two is a dominating mechanism in soil VOC exchange.

In general, hemiboreal forests have a higher proportion of deciduous trees compared to boreal forests (Bourtsoukidis et al. 2014a) which traditionally are managed as conifer monocultures with only sporadic understorey with deciduous tree saplings. In the future, the warming climate may lead to significant changes in forest tree distribution and transform boreal coniferous forests into mixed forests, resembling more the hemiboreal forest type. This will likely also change soil characteristics and affect the VOC emissions from forest floor. Smolander and Kitunen (2011) found that soil $\mathrm{pH}, \mathrm{NH} 4-$ concentrations and carbon and nitrogen content in microbial biomass were higher in boreal birch stands compared to Norway spruce and Scots pine stands, especially in older stands. This indicates that increased abundance of broadleaf species may accelerate microbial activity and nutrient availability in soil, potentially affecting microbial VOC synthesis and uptake, and increasing VOC biosynthesis and emissions also from the ground vegetation. This study showed that large differences in fluxes can be seen between stands with only conifers and those with mixed tree species composition. Our results show the need for detailed experiments to clarify the driving processes in these different stands. Without such understanding it is very difficult to forecast future emissions from forest soil and forest floor vegetation.

Acknowledgements We thank and acknowledge the funding from the Jenny and Antti Wihuri Foundation, the Academy of Finland Centre of Excellence program (project no 272041) and Academy of Finland projects 130984, 275608 and 286685. Financial support was further granted by the Ministry of Education and Research of Estonia (basal funding grants P170026 and P18002); the Estonian Research Infrastructures Roadmap project Estonian Environmental Observatory (3.2.0304.11-0395); the European Commission via ERA-NET-Cofund action ERA PLANET (689443), Centre of Excellence EcolChange, and the European Social Fund (Mobilitas post-doctoral grant MJD 257). We thank Beate Noe for the processing of the litter samples at SMEAR Estonia.

Author contribution M. Mäki was responsible for preparing the manuscript and analysing results. Field measurements were performed by M. Mäki and D. Krasnov. The experimental planning and writing of the manuscript were done in collaboration with all co-authors.

Funding Information Open access funding provided by University of Helsinki including Helsinki University Central Hospital. 
Data availability statement All data analysed during this study are included in this published article and its supplementary information files.

\section{Compliance with ethical standards}

Disclaimer We as authors confirm no competing financial interests and we also affirm that this manuscript has not been submitted elsewhere.

Open Access This article is distributed under the terms of the Creative Commons Attribution 4.0 International License (http:// creativecommons.org/licenses/by/4.0/), which permits unrestricted use, distribution, and reproduction in any medium, provided you give appropriate credit to the original author(s) and the source, provide a link to the Creative Commons license, and indicate if changes were made.

\section{References}

Aaltonen H, Pumpanen J, Pihlatie M, Hakola H, Hellén H, Kulmala L, Vesala T, Bäck J (2011) Boreal pine forest floor biogenic volatile organic compound fluxes peak in early summer and autumn. Agric For Meteorol 151:682-691. https://doi.org/10.1016/j.agrformet.2010.12.010

Aaltonen H, Aalto J, Kolari P, Pihlatie M, Pumpanen J, Kulmala M, Nikinmaa E, Vesala T, Bäck J (2013) Continuous VOC flux measurements on boreal forest floor. Plant Soil 369:241256. https://doi.org/10.1007/s11104-012-1553-4

Albers CN, Kramshøj M, Rinnan R (2018) Rapid mineralization of biogenic volatile organic compounds in temperate and Arctic soils. Biogeosciences 15:3591-3601. https://doi. org/10.5194/bg-15-3591-2018

Asensio D, Peñuelas J, Filella I, Llusià J (2007a) On-line screening of soil VOCs exchange responses to moisture, temperature and root presence. Plant Soil 291:249-261. https://doi. org/10.1007/s11104-006-9190-4

Asensio D, Peñuelas J, Llusià J, Ogaya R, Filella I (2007b) Interannual and interseasonal soil $\mathrm{CO} 2$ efflux and VOC exchange rates in a Mediterranean holm oak forest in response to experimental drought. Soil Biol Biochem 39: 2471-2484. https://doi.org/10.1016/j.soilbio.2007.04.019

D. Asensio, J. Peñuelas, P. Prieto, M. Estiarte, I. Filella, J. Llusià, (2008) Interannual and seasonal changes in the soil exchange rates of monoterpenes and other VOCs in a Mediterranean shrubland. European Journal of Soil Science 59 (5):878-891

Bäck J, Aaltonen H, Hellén H, Kajos MK, Patokoski J, Taipale R, Pumpanen J, Heinonsalo J (2010) Variable fluxes of microbial volatile organic compounds (MVOCs) from root associated fungi isolated from scots pine. Atmos Environ 44:36513659. https://doi.org/10.1016/j.atmosenv.2010.06.042

Bourtsoukidis E, Bonn B, Noe SM (2014a) On-line field measurements of BVOC emissions from Norway spruce (Picea abies) at the hemiboreal SMEAR-Estonia site under autumn conditions. Boreal Environ Res 19:153-167
Bourtsoukidis E, Kawaletz H, Radacki D, Schütz S, Hakola H, Hellén H, Noe S, Mölder I, Ammer C, Bonn B (2014b) Impact of flooding and drought conditions on the emission of volatile organic compounds of Quercus robur and Prunus serotina. Trees 28:193-204. https://doi.org/10.1007/s00468013-0942-5

Bourtsoukidis E, Behrendt T, Yañez-Serrano AM, Hellén H, Diamantopoulos E, Catão E, Ashworth K, Pozzer A, Quesada CA, Martins DL, Sá M, Araujo A, Brito J, Artaxo P, Kesselmeier J, Lelieveld J, Williams J (2018) Strong sesquiterpene emissions from Amazonian soils. Nat Commun 9(2226):2226. https://doi.org/10.1038/s41467018-04658-y

Bracho-Nunez A, Knothe NM, Costa WR, Maria Astrid LR, Kleiss B, Rottenberger S, Piedade MF, Kesselmeier J (2012) Root anoxia effects on physiology and emissions of volatile organic compounds (VOC) under short- and longterm inundation of trees from Amazonian floodplains. SpringerPlus 1, 1-16. https://doi.org/10.1186/2193-1801-1-9

Brockett BFT, Prescott CE, Grayston SJ (2012) Soil moisture is the major factor influencing microbial community structure and enzyme activities across seven biogeoclimatic zones in western Canada. Soil Biol Biochem 44:9-20. https://doi. org/10.1016/j.soilbio.2011.09.003

Cederlund H, Wessén E, Enwall K, Jones CM, Juhanson J, Pell M, Philippot L, Hallin S (2014) Soil carbon quality and nitrogen fertilization structure bacterial communities with predictable responses of major bacterial phyla. Appl Soil Ecol 84:62-68. https://doi.org/10.1016/j.apsoil.2014.06.003

Cho C, Sung K, Coapcioglu MY, Drew M (2005) Influence of water content and plants on the dissipation of chlorinated volatile organic compounds in soil. Water Air Soil Pollut 167: 259-271

Cleveland CC, Yavitt JB (1998) Microbial consumption of atmospheric isoprene in a temperate forest soil. Appl Environ Microbiol 64:172-177

Cornelissen JHC, van Bodegom PM, Aerts R, Callaghan TV, van Logtestijn RSP, Alatalo J, Chapin FS, Gerdol R, Gudmundsson J, Gwynn-Jones D, Hartley AE, Hik DS, Hofgaard A, Jonsdottir IS, Karlsson S, Klein JA, Laundre J, Magnusson B, Michelsen A, Molau U, Onipchenko VG, Quested HM, Sandvik SM, Schmidt IK, Shaver GR, Solheim B, Soudzilovskaia NA, Stenström A, Tolvanen A, Totland Ø, Wada N, Welker JM, Zhao X, Team MOL (2007) Global negative vegetation feedback to climate warming responses of leaf litter decomposition rates in cold biomes. Ecol Lett 10:619-627. https://doi.org/10.1111/j.14610248.2007.01051.x

Cornwell WK, Cornelissen JHC, Amatangelo K, Dorrepaal E, Eviner VT, Godoy O, Hobbie SE, Hoorens B, Kurokawa H, Pérez-Harguindeguy N, Quested HM, Santiago LS, Wardle DA, Wright IJ, Aerts R, Allison SD, Van Bodegom P, Brovkin V, Chatain A, Callaghan TV, Díaz S, Garnier E, Gurvich DE, Kazakou E, Klein JA, Read J, Reich PB, Soudzilovskaia NA, Vaieretti MV, Westoby M (2008) Plant species traits are the predominant control on litter decomposition rates within biomes worldwide. Ecol Lett 11:10651071

Cousins IT, Angus JB, Jones KC (1999) A review of the processes involved in the exchange of semi-volatile organic compounds (SVOC) across the air-soil interface. Sci Total 
Environ 228:5-24. https://doi.org/10.1016/S0048-9697(99 )00015-7

Davidson EA, Janssens IA (2006) Temperature sensitivity of soil carbon decomposition and feedbacks to climate change. Nature 440:165-173. https://doi.org/10.1038/nature04514

L Deng, P Yuan, D Liu, F Annabi-Bergaya, J Zhou, F Chen, Z Liu, (2017) Effects of microstructure of clay minerals, montmorillonite, kaolinite and halloysite, on their benzene adsorption behaviors. Applied Clay Science 143:184-191

Ditengou FA, Müller A, Rosenkranz M, Felten J, Lasok H, van Doorn MM, Legue V, Palme K, Schnitzler JP, Polle A (2015) Volatile signalling by sesquiterpenes from ectomycorrhizal fungi reprogrammes root architecture. Nat Commun 6(6279): 6279. https://doi.org/10.1038/ncomms7279

Fall R, Karl T, Jordan A, Lindinger W (2001) Eddy covariance measurement of biogenic oxygenated VOC emissions from hay harvesting. Atmos Environ 35:491-495

Faubert P, Tiiva P, Rinnan Á, Michelsen A, Holopainen JK, Rinnan R (2010) Doubled volatile organic compound emissions from subarctic tundra under simulated climate warming. New Phytol 187:199-208. https://doi.org/10.1111 /J.1469-8137.2010.03270.X

Faubert P, Tiiva P, Michelsen A, Rinnan Å, Ro-Poulsen H, Rinnan $R$ (2012) The shift in plant species composition in a subarctic mountain birch forest floor due to climate change would modify the biogenic volatile organic compound emission profile. Plant Soil 352:199-215. https://doi.org/10.1007 /s11104-011-0989-2

Gray CM, Monson RK, Fierer N (2010) Emissions of volatile organic compounds during the decomposition of plant litter. $\mathrm{J}$ Geophys Res 115:G03015. https://doi.org/10.1029/2010 JG001291

Greenberg JP, Asensio D, Turnipseed A, Guenther AB, Karl T, Gochis D (2012) Contribution of leaf and needle litter to whole ecosystem BVOC fluxes. Atmos Environ 59:302311. https://doi.org/10.1016/j.atmosenv.2012.04.038

Guenther AB, Zimmerman PR, Harley PC, Monson RK, Fall R (1993) Isoprene and monoterpene emission rate variability: model evaluations and sensitivity analyses. J Geophys Res Atmos (1984-2012) 98:12609-12617. https://doi. org/10.1029/93JD00527

Hakola H, Hellén H, Tarvainen V, Bäck J, Patokoski J, Rinne J (2009) Annual variations of atmospheric VOC concentrations in a boreal forest. Boreal Environ Res 14:722-730

Hakola H, Tarvainen V, Praplan AP, Jaars K, Hemmilä M, Kulmala M, Bäck J, Hellén H (2017) Terpenoid and carbonyl emissions from Norway spruce in Finland during the growing season. Atmos Chem Phys 17:3357-3370. https://doi. org/10.5194/acp-17-3357-2017

Hanson DT, Swanson S, Graham LE, Sharkey TD (1999) Evolutionary significance of isoprene emission from mosses. Am J Bot 86:634-639

Hansson K, Olsson BA, Olsson M, Johansson U, Kleja DB (2011) Differences in soil properties in adjacent stands of Scots pine, Norway spruce and silver birch in SW Sweden. For Ecol Manag 262(3):522-530. https://doi.org/10.1016/j. foreco.2011.04.021

Hansson K, Helmisaari HS, Sah SP, Lange H (2013a) Fine root production and turnover of tree and understorey vegetation in Scots pine, silver birch and Norway spruce stands in SW
Sweden. For Ecol Manag 309:58-65. https://doi.org/10.1016 /j.foreco.2013.01.022

Hansson K, Fröberg M, Helmisaari HS, Kleja DB, Olsson BA, Olsson M, Persson T (2013b) Carbon and nitrogen pools and fluxes above and below ground in spruce, pine and birch stands in southern Sweden. For Ecol Manag 309:28-35. https://doi.org/10.1016/j.foreco.2013.05.029

Hayward S, Muncey RJ, James AE, Halsall CJ, Hewitt CN (2001) Monoterpene emissions from soil in a Sitka spruce forest. Atmos Environ 35:4081-4087. https://doi.org/10.1016 /S1352-2310(01)00213-8

Hedwall P-O, Skoglund J, Linder S (2015) Interactions with successional stage and nutrient statusdetermines the lifeform-specific effects of increased soil temperature on boreal forest floor vegetation. Ecol Evol 2015 5(4):948-960. https://doi.org/10.1002/ece3.1412

Hellén H, Hakola H, Pystynen KH, Rinne J, Haapanala S (2006) C2-C10 hydrocarbon emissions from a boreal wetland and forest floor. Biogeosciences 3:167-174. https://doi. org/10.5194/bg-3-167-2006

Hickler T, Vohland K, Feehan J, Miller PA, Smith B, Costa L, Giesecke T, Fronzek S, Carter TR, Cramer W, Kühn I, Sykes MT (2012) Projecting the future distribution of European potential natural vegetation zones with a generalized, tree species-based dynamic vegetation model. Glob Ecol Biogeogr 21:50-63. https://doi.org/10.1111/j.14668238.2010.00613.x

Hobbie SE (1996) Temperature and plant species control over litter decomposition in Alaskan tundra. Ecol Monogr 66: 503-522. https://doi.org/10.2307/2963492

Ilvesniemi H, Pumpanen J, Duursma R, Hari P, Keronen P, Kolari P, Kulmala M, Mammarella I, Nikinmaa E, Rannie U, Pohja T, Siivola E, Vesala T (2010) Water balance of a boreal Scots pine forest. Boreal Environ Res 15:375-396

H Insam, MSA Seewald, (2010) Volatile organic compounds (VOCs) in soils. Biology and Fertility of Soils 46 (3):199-213

Isidorov VA, Vinogorova VT, Rafalowski K (2003) HS-SPME analysis of volatile organic compounds of coniferous needle litter. Atmos Environ 37:4645-4650

Isidorov VA, Vinogorova VT, Rafalowski K (2005) Gas chromatographic determination of extractable compounds and emission rate of volatile terpenes from larch needle litter. $\mathrm{J}$ Atmos Chem 50:263-278

Isidorov VA, Smolewska M, Purzynska-Pugacewicz A, Tyszkiewicz Z (2010) Chemical composition of volatile and extractive compounds of pine and spruce leaf litter in the initial stages of decomposition. Biogeosciences 7:27852794. https://doi.org/10.5194/bg-7-2785-2010

Isidorov V, Tyszkiewicz S, Piroznikow E (2016) Fungal succession in relation to volatile organic compounds emissions from scots pine and Norway spruce leaf litter-decomposing fungi. Atmos Environ 131:301-306. https://doi.org/10.1016 /j.atmosenv.2016.02.015

Janson RW (1993) Monoterpene emissions from Scots pine and Norwegian spruce. J Geophys Res 98:2839-2850. https://doi.org/10.1029/92JD02394

Joensuu J, Altimir N, Hakola H, Rostás M, Raivonen M, Vestenius M, Aaltonen H, Riederer M, Bäck J (2016) Role of needle surface waxes in dynamic exchange of mono- and sesquiterpenes. Atmos Chem Phys 16:7813-7823. https://doi. org/10.5194/acp-16-7813-2016 
Jokinen T, Berndt T, Makkonen R, Kerminen VM, Junninen H, Paasonen P, Stratmann F, Herrmann H, Guenther AB, Worsnop DR (2015) Production of extremely low volatile organic compounds from biogenic emissions. Measured yields and atmospheric implications. Proc Natl Acad Sci U S A 112:7123-7128. https://doi.org/10.1073 /pnas. 1423977112

Kainulainen P, Holopainen JK (2002) Concentrations of secondary compounds in Scots pine needles at different stages of decomposition. Soil Biol Biochem 34:37-42. https://doi. org/10.1016/S0038-0717(01)00147-X

Kanerva S, Smolander A (2007) Microbial activities in forest floor layers under silver birch Norway spruce and scots pine. Soil Biol Biochem 39:1459-1467

Kellomäki S, Rouvinen I, Peltola H, Strandman H, Steinbrecher R (2001) Impact of global warming on the tree species composition of boreal forests in Finland and effects on emissions of isoprenoids. Glob Chang Biol 7:531-544. https://doi. org/10.1046/j.1365-2486.2001.00414.x

Kellomäki S, Peltola H, Nuutinen T, Korhonen KT, Strandman H (2008) Sensitivity of managed boreal forests in Finland to climate change, with implications for adaptive management. Philos Trans R Soc B 363:2341-2351. https://doi. org/10.1098/rstb.2007.2204

Kesselmeier J, Staudt M (1999) Biogenic Volatile Organic Compound (VOC): an overview on emissions, Physiology and Ecology. Journal of Atmospheric Chemistry 33:23-88. https://doi.org/10.1023/A:1006127516791

Lathiere J, Hauglustaine DA, De Noblet-Ducoudre N, Krinner G, Folberth GA (2005) Past and future changes in biogenic volatile organic compound emissions simulated with a global dynamic vegetation model. Geophys Res Lett 32:L20818. https://doi.org/10.1029/2005GL024164

Leff JW, Fierer N (2008) Volatile organic compound (VOC) emissions from soil and litter samples. Soil Biol Biochem 40(7): 1629-1636. https://doi.org/10.1016/j. soilbio.2008.01.018

Lin C, Owen SM, Peñuelas J (2007) Volatile organic compounds in the roots and rhizosphere of Pinus spp. Soil Biol Biochem 39:951-960. https://doi.org/10.1016/j.soilbio.2006.11.007

Lindwall F, Faubert P, Rinnan R (2015) Diel variation of biogenic volatile organic compound emissions - a field study in the sub, low and high arctic on the effect of temperature and light. PLoS One 10(4):e0123610. https://doi.org/10.1371 /journal.pone.0123610

Mäki M, Heinonsalo J, Hellén H, Bäck J (2017) Contribution of understorey vegetation and soil processes to boreal forest isoprenoid exchange. Biogeosciences 14:1055-1073. https://doi.org/10.5194/bg-14-1055-2017

Mäki M, Aalto J, Hellén H, Pihlatie M, Bäck J (2019) Interannual and seasonal dynamics of volatile organic compound fluxes from the boreal Forest floor. Front Plant Sci 10:191. https://doi.org/10.3389/fpls.2019.00191

Näsholm T, Ekblad A, Nordin A, Giesler R, Hogberg M, Hogberg $\mathrm{P}$ (1998) Boreal forest plants take up organic nitrogen. Nature 392:914-916. https://doi.org/10.1038/31921

Noe SM, Kimmel V, Hüve K, Copolovici L, Portillo-Estrada M, Püttsepp Ü, Jõgiste K, Niinemetsa Ü, Hörtnagl L, Wohlfahrt G (2011) Ecosystem-scale biosphere-atmosphere interactions of a hemiboreal mixed forest stand at Järvselja, Estonia. For Ecol Manag 262:71-81
Noe SM, Hüve K, Niinemets U, Copolovici L (2012) Seasonal variation in vertical volatile compounds air concentrations within a remote hemiboreal mixed forest. Atmos Chem Phys 12:3909-3926. https://doi.org/10.5194/acp-12-3909-2012

Noe SM, Niinemets Ü, Krasnova A, Krasnov D, Motallebi A, Kängsepp V, Jõgiste K, Hõrrak U, Komsaare K, Mirme S, Vana M, Tammet H, Bäck J, Vesala T, Kulmala M, Petäjä T, Kangur A (2015) SMEAR Estonia: perspectives of a largescale forest ecosystem - atmosphere research infrastructure. Forestry Studies | Metsanduslikud Uurimused 63:56-84

Noe SM, Krasnov D, Krasnova A, Cordey HPE, Niinemets Ü (2016) Seasonal variation and characterisation of reactive trace gas mixing ratios over a hemi-boreal mixed forest site in Estonia. Boreal Environ Res 21:332-344

Park T, Ganguly S, Tømmervik H, Euskirchen ES, Høgda K-A, Karlsen SR, Brovkin V, Nemani RR, Myneni RB (2016) Changes in growing season duration and productivity of northern vegetation inferred from long-term remote sensing data. Environ Res Lett 11:084001. https://doi.org/10.1088 /1748-9326/11/8/084001

Priha O, Grayston SJ, Hiukka R, Pennanen T, Smolander A (2001) Microbial community structure and characteristics of the organic matter in soils under Pinus sylvestris, Picea abies and Betula pendula at two forest sites. Biol Fertil Soils 33: $17 \mathrm{e} 24$

Pumpanen J, Kolari P, Ilvesniemi H, Minkkinen K, Vesala T, Niinistö S, Lohila A, Larmola T, Moreto M, Pihlatie M, Janssen I, Yuester JC, Grunzweig JM, Reth S, Subke J-A, Savage K, Kutsch W, Østreng G, Ziegler W, Anthoni P, Lindroth A, Hari P (2004) Comparison of different chamber techniques for measuring soil $\mathrm{CO} 2$ efflux. Agric For Meteorol 123:159-176. https://doi.org/10.1016/j. agrformet.2003.12.001

Ramirez KS, Lauber CL, Fierer N (2010) Microbial consumption and production of volatile organic compounds at the soillitter interface. Biogeochemistry 99:97-107. https://doi. org/10.1007/S10533-009-9393-X

Rantala P, Taipale R, Aalto J, Kajos MK, Patokoski J, Ruuskanen TM, Rinne J (2014) Continuous flux measurements of VOCs using PTR-MS - reliability and feasibility of disjunct-eddycovariance, surface-layer-gradient, and surface-layer-profile methods. Boreal Environ Res 19:87-107

Rinnan R, Michelsen A, Jonasson S (2008) Effects of litter addition and warming on soil carbon, nutrient pools and microbial communities in a subarcticheathecosystem. Appl Soil Ecol 39:271-281. https://doi.org/10.1016/j.apsoil.2007.12.014

Rinnan R, Gierth D, Bilde M, Rosenørn T, Michelsen A (2013) Off-season biogenic volatile organic compound emissions from heath mesocosms: responses to vegetation cutting. Front Microbiol 4:1-10. https://doi.org/10.3389 /fmicb.2013.00224

Rossabi S, Choudoir M, Helmig D, Hueber J, Fierer N (2018) Volatile organic compound emissions from soil following wetting events. J Geophys Res Biogeosci 123(6):19882001. https://doi.org/10.1029/2018JG004514

Seewald MSA, Singer W, Knapp BA, Franke-Whittle IH, Hansel A, Insam H (2010) Substrate-induced volatile organic compound emissions from compost-amended soils. Biol Fertil Soils 46(4):371-382. https://doi.org/10.1007/s00374-0100445-0 
Sindelarova K, Granier C, Bouarar I, Guenther A, Tilmes S, Stavrakou T, Müller JF, Kuhn U, Stefani P, Knorr W (2014) Global data set of biogenic VOC emissions calculated by the MEGAN model over the last 30 years. Atmos Chem Phys 14: 9317-9341. https://doi.org/10.5194/acp-14-9317-2014

Skopp J, Jawson MD, Doran JW (1990) Steady-state aerobic microbial activity as a function of soil-water content. Soil Sci Soc Am J 54:1619-1625. https://doi.org/10.2136 /sssaj1990.03615995005400060018x

Smolander A, Kitunen V (2011) Comparison of tree species effects on microbial $\mathrm{C}$ and $\mathrm{N}$ transformations and dissolved organic matter properties in the organic layer of boreal forests. Appl Soil Ecol 49(2011):224-233. https://doi. org/10.1016/j.apsoil.2011.05.002

Smolander A, Ketola RA, Kotiaho T, Kanerva S, Suominen K, Kitunen V (2006) Volatile monoterpenes in soil atmosphere under birch and conifers: effects on soil $\mathrm{N}$ transformations. Soil Biol Biochem 38:3436-3442

Som S, Willet DS, Alborn HT (2017) Dynamics of belowground volatile diffusion and degradation. Rhizosphere 4:70-74. https://doi.org/10.1016/j.rhisph.2017.07.004

Svendsen S, Lindwall F, Michelsen A, Rinnan R (2016) Biogenic volatile organic compound emissions along a high arctic soil moisture gradient. Sci Total Environ 573:131-138

Tape K, Sturm M, Racine C (2006) The evidence for shrub expansion in northern Alaska and the pan-Arctic. Glob Chang Biol 12:686-702

Valolahti HM, Kivimäenpää P, Faubert A, Michelsen A, Rinnan R (2015) Climate change-induced vegetation change as a driver of increased subarctic biogenic volatile organic compound emissions. Glob Chang Biol 21:3478-3488
Veres PR, Behrendt T, Klapthor A, Meixner FX, Williams J (2014) Volatile organic compound emissions from soil: using proton-transfer-reaction time-of-flight mass spectrometry (PTR-TOF-MS) for the real time observation of microbial processes. Biogeosci Discuss 11:12009-12038

Vuorinen KEM, Oksanen L, Oksanen T, Pyykönen A, Olofsson J, Virtanen R (2017) Open tundra persist, but arctic features decline-vegetation changes in the warming Fennoscandian tundra. Glob Chang Biol 23:3794-3807. https://doi. org/10.1111/gcb.13710

Wang M, Schurgers G, Hellen H, Lagergren F, Holst T (2018) Biogenic volatile organic compound emissions from a boreal forest floor. Boreal Environ Res 23:249-265

Warneke C, Karl T, Judmaier H, Hansel A, Jordan A, Lindinge W (1999) Acetone, methanol, and other partially oxidized volatile organic emissions from dead plant matter by abiological processes: significance for atmospheric $\mathrm{HOx}$ chemistry. Glob Biogeochem Cycles 13:9-17

Zhong L, Cantrell K, Mitroshkov A, Shewell J (2014) Mobilization and transport of organic compounds from reservoir rock and caprock in geological carbon sequestration sites. Environ Earth Sci 71(9):4261-4272. https://doi. org/10.1007/s12665-013-2823-Z

Publisher's note Springer Nature remains neutral with regard to jurisdictional claims in published maps and institutional affiliations. 